\section{HUELLAS DE LA CIUDAD. REFLEXIONES SOBRE LA RELACIÓN ENTRE CIUDAD, MONUMENTO Y FOTOGRAFÍA A PARTIR DE WALTER BENJAMIN ${ }^{1}$}

\author{
Ana María Rabe \\ Investigadora, Instituto de Filosofía (CCHS/CSIC) \\ c/ Albasanz 26-28, 28037 Madrid \\ ana.rabe@cchs.csic.es
}

\begin{abstract}
TRACES OF THE CITY. REFLECTIONS ON THE RELATIONSHIP BETWEEN CITY, MONUMENT AND PHOTOGRAPHY BASED ON WALTER BENJAMIN'S WORK
\end{abstract}

\begin{abstract}
There is a deep relationship between monument and photography which is practically inseparable in the case of a town's landmark. The monument and moreover the town's landmark needs to be reproduced, and that means firstly: shot. But do we really see the town when we are contemplating monuments or their reproduction? Current life of a town presents itself in thousand ways. But no thousand pictures are able to compose the face of a town. If one seeks to reflect it, one has to do more than to reproduce that what presents itself with ostentation; one has to catch in flight what appears disappearing in a fugacious moment. For this, it's necessary to catch the accidental trace behind the intentional traces. Holding a dialogue with Walter Benjamin as well as with Alfred Döblin, this text reflects on the relationship between picture and remembrance as well as the different dimensions of time, and in this connection on possibilities and limits in representing life and character of a town.
\end{abstract}

KEY WORDS: Town; monument; photography; remembrance; time; picture; trace.

\section{LA CIUDAd Y EL VESTUARIO DEL LEgADO}

En el prefacio de un libro de fotografías de Berlín de 1928 comenta el escritor alemán Alfred Döblin:

Berlín es una ciudad nada poética, de poco color, pero muy verdadera. Cuando los grandes autobuses salen con los forasteros del Jardín Zoológico, de la Plaza de Potsdam, desde Unter den Linden, pueden estar seguros de que el chófer y el guía que explica conducen los coches bajo una falsa ilusión poética. Ya lo veo desde lejos, van a conducir los coches en una falsa dirección, pues van a atravesar... París, pero no Berlín. Van a cruzar el parque del Tiergarten, van
RESUMEN: Hay una relación estrecha entre monumento y fotografía, que es prácticamente inseparable en el caso del símbolo de la ciudad. El monumento y más el símbolo de una ciudad necesita ser reproducido, lo cual quiere decir en primer lugar: fotografiado. ¿Pero vemos realmente la ciudad cuando contemplamos los monumentos o bien la reproducción de los mismos? La vida actual de la ciudad se manifiesta de mil maneras. Pero no son mil imágenes las que componen el rostro de la ciudad. Para reflejarlo, no basta con reproducir lo que se presenta ostensivamente; hay que atrapar al vuelo lo que aparece desapareciendo en un momento fugaz. Para ello hace falta atrapar las huellas casuales tras aquellas intencionales. En diálogo con Walter Benjamin y también con Alfred Döblin se reflexiona en este texto sobre la relación de la imagen con el recuerdo y las diferentes dimensiones del tiempo, y en este contexto sobre posibilidades y límites de la representación de la vida y el carácter de una ciudad.

PALABRAS CLAVE: Ciudad; monumento; fotografía; recuerdo; tiempo; imagen; huella.

a mostrar la Columna de la Victoria, luego se presenta la indestructible Siegesallee [Avenida de la Victoria], aparece la Puerta de Brandenburgo, luego la Avenida Unter den Linden, los palacios, el Zeughaus [arsenal], los museos y qué más. Se contempla el ayuntamiento, la Casa Municipal, se atraviesa la Plaza de Potsdam, se sigue por la ribera de Lützow hasta la Gedöchtniskirche [Iglesia de la Memoria], se va también más lejos, a Sanssouci, se ven unos grandes almacenes u otros. Y el forastero contempla todo esto, y si es inteligente reprime el pensamiento: Esto todo lo encontramos mejor en otro lado, en Paris, en Londres. El forastero también encuentra un puñado de locales de diversión, pero si tiene experiencia, bosteza allí, o le saltan las lágrimas por nostalgia. A fin de 
cuentas, piensa el forastero, no pasa mucho en esta ciudad. Constata, sin saberlo, que se ha equivocado de dirección: Es una ciudad grande, aburrida e inquieta. No tiene color. Un día en el pasado, algunas personas llamativas, con ganas de construir, deben de haber atravesado la ciudad dejando atrás alguna cosa: Uno un palacio, el otro un museo, el tercero Sanssouci, quizás fueron los reyes. Ahora, todo eso está allí, son regalos con los que la gente no sabe hacer nada, y la gente pasa por ahi, hace, indiferente, sus negocios como en otras ciudades: Berlín, pues, no se planificó sistemáticamente.

Si, esto es correcto. Berlín consiste en primer lugar del legado de un número de gente que ha muerto y en segundo lugar de lo que hace la gente de hoy.

La primera parte es accesible a cualquiera en forma de una visita de cementerio (visita turistica), cada pieza individual del vestuario del legado y los edificios se dejan, ciertamente, fotografiar bien. La mayor parte de la segunda parte, sin embargo, no se puede fotografiar, o no merece la pena fotografiar. Con otras palabras: Berlín es mayormente invisible. Cosa curiosa: En el caso de Francfort del Meno, Múnich, esto no es así, ¿o me equivoco? ¿Puede que acaso todas las ciudades modernas sean en el fondo invisibles, [...] y que lo que es visible de ellas es sólo el vestuario del legado? Sería magnífico. Pero sería un buen símbolo para todo lo espiritual de hoy. Pues con nuestras ideas y nuestros pensamientos no ocurre otra cosa, son mayormente de ayer y antesdeayer, y con infinita lentitud, el hoy va penetrando en nuestros pensa- mientos. Y así, poco a poco, se van reformando las ciudades, quizás podrá verse Berlín entre 50 y 100 años de ahora en adelante, desde luego: el de hoy (von Bucovich, 1992, s. p.).

Para empezar a desarrollar la relación entre ciudad, monumento y fotografía que nos hemos propuesto presentar aquí, cabe resaltar tres puntos esenciales del texto que acabamos de citar. El primero es la caracterización -claramente irónica- de la Siegesallee (Avenida de la Victoria), que conduce a la Columna de la Victoria, como "indestructible" (figs. 1 y 2). El segundo punto esencial del texto de Döblin es la denominación, igualmente irónica, de la visita turística como "visita de cementerio" y en ese contexto de los monumentos como "piezas individuales del vestuario del legado" de un "número de gente que ha muerto". Y el tercer punto es la afirmación de que el presente va penetrando con infinita lentitud en nuestros pensamientos, mientras se van reformando las ciudades, de manera que dentro de 50 o incluso 100 años será posible ver Berlín, aunque, desde luego, el Berlín que se verá, será entonces una ciudad del pasado. Con estos tres comentarios se abre el panorama temporal en el que se insertan las ciudades con sus monumentos: primero el futuro, que encontramos en la promesa de la indestructibilidad de una avenida emblemática de Berlín -tenía que ser la avenida coronada con el nombre de la "victoria" que sugiere un futuro glorioso, más que una guerra pasada-, luego el pasado, que se concretiza en el cementerio, los

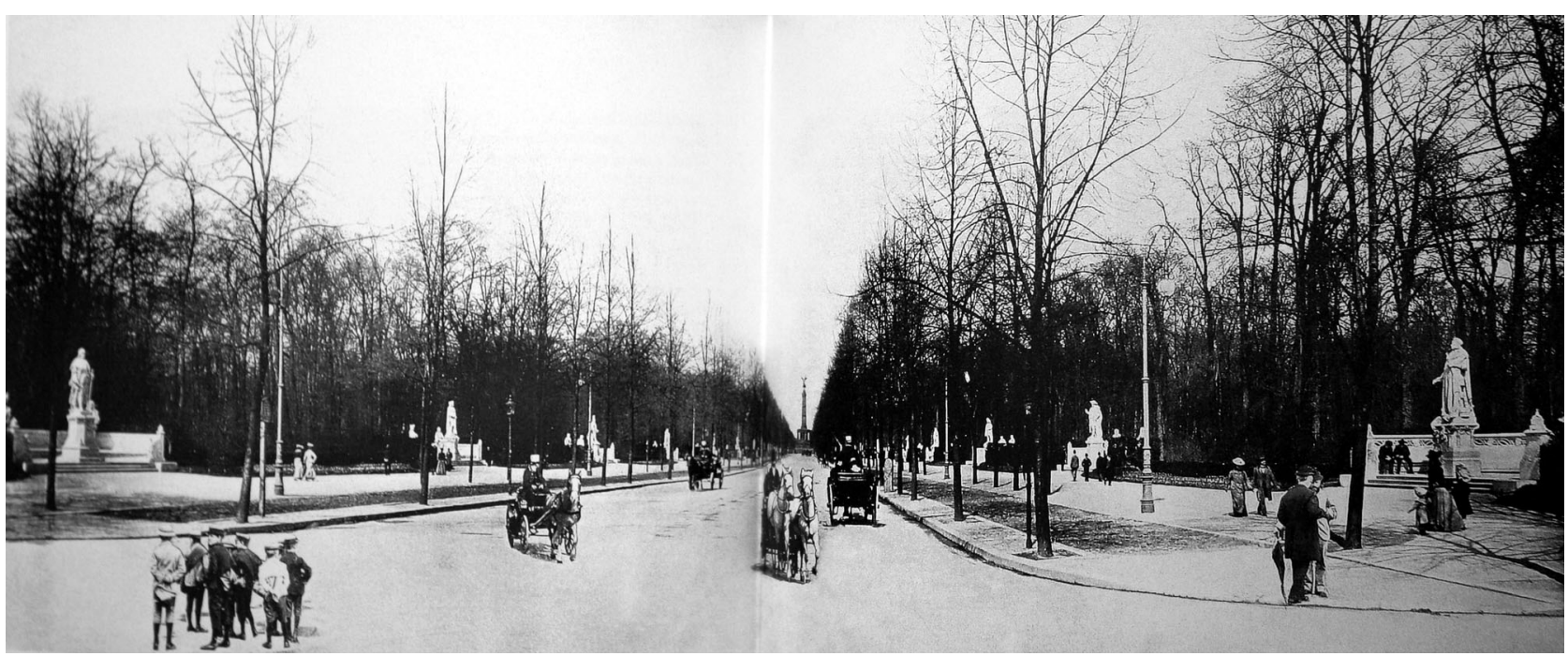

Figura 1. Siegesallee (Avenida de la Victoria), Berlín, hacia 1910. 


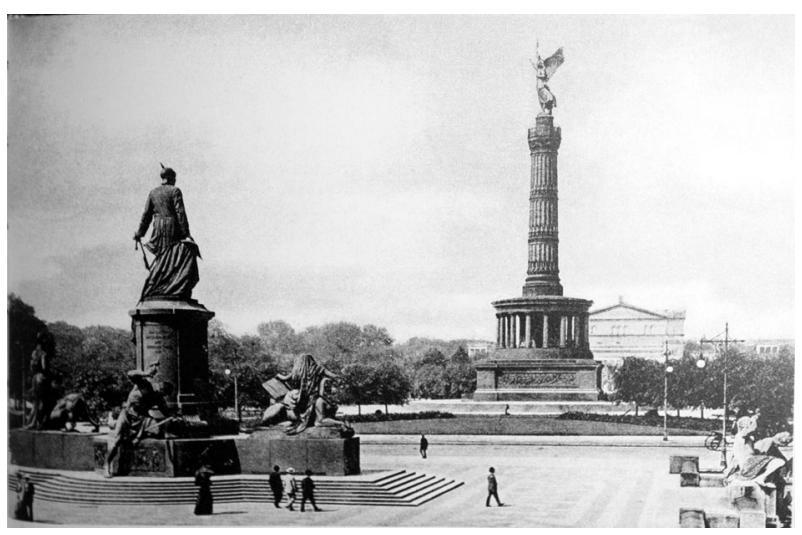

Figura 2. Monumento a Bismarck y Columna da la Victoria, Berlín, 1915.

muertos y el legado, y finalmente el presente que siempre se escapa, bien al futuro, en la anticipación, o bien al pasado, en el recuerdo.

Para nuestro tema, que se centra en la relación entre monumento, ciudad y fotografía, estos tres aspectos son fundamentales. Los monumentos, al menos los "intencionados" que el historiador de arte austriaco Alois Riegl diferencia de los monumentos históricos "no intencionados", conllevan una dimensión futura esencial, en el sentido de que tienen el fin de perdurar y pasar de generación en generación para dar testimonio de personajes y sucesos importantes de la historia. En su texto El culto moderno de los monumentos, de 1903, Alois Riegl, afirma que

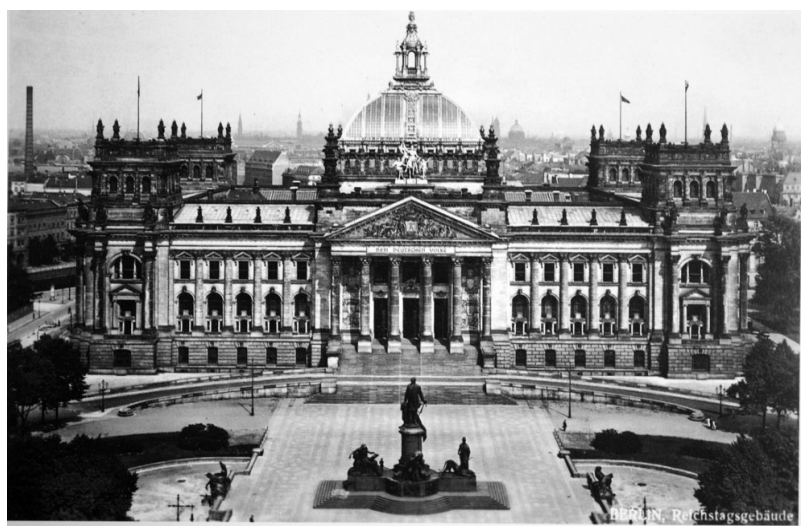

Figura 3. El edificio del Reichstag (Parlamento), Berlín, hacia 1930.
[P]or monumento, en el sentido más antiguo y primigenio, se entiende una obra realizada por la mano humana y creada con el fin específico de mantener hazañas o destinos individuales (o un conjunto de éstos) siempre vivos y presentes en la conciencia de las generaciones venideras" (Riegl, 2007, 51).

Con su fin, que señala al futuro, los monumentos apuntan también al pasado, que es la segunda dimensión temporal que hemos destacado antes. En este contexto es interesante señalar el vínculo del término "monumento" con la palabra monumentum que significa sepulcro. Con ello, la asociación con el cementerio, que nos sugirió Döblin, no presenta sólo un comentario irónico con respecto al carácter de los monumentos y al culto que se les rinde, un culto fúnebre, sino que también tiene una vertiente etimológica.

Finalmente está la dimensión complicada del presente que siempre se escapa, a diferencia de determinadas imágenes que creamos para compensar esa constante fuga y que proyectamos sobre el pasado y el futuro. Pues, aunque el fin de los monumentos es perdurar, lo cierto es que también perecen, igual que el hombre. Tal vez lo hagan con más lentitud, pero al final sucumben también a la ley del tiempo; las ciudades se van reformando, se destruyen, los monumentos quedan en ruinas, se convierten en huérfanos aislados o separados de su contexto y lugar original, si no se desmoronan del todo (figs. 3-6).

También la Siegesallee que Döblin apelaba como "indestructible" ha desaparecido del mapa berlinés. No existen

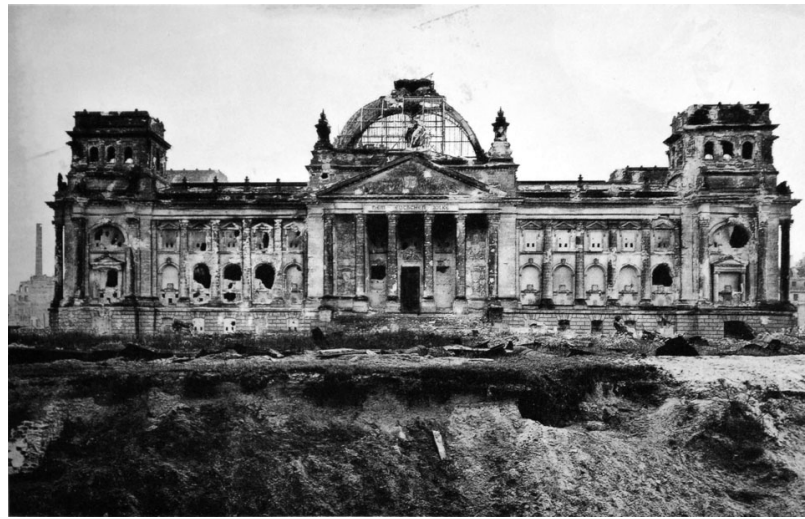

Figura 4. El edificio destruido del Reichstag, Berlín, 1945.

ARBOR Vol. 187747 enero-febrero [2011] 143-168 ISSN: 0210-1963 


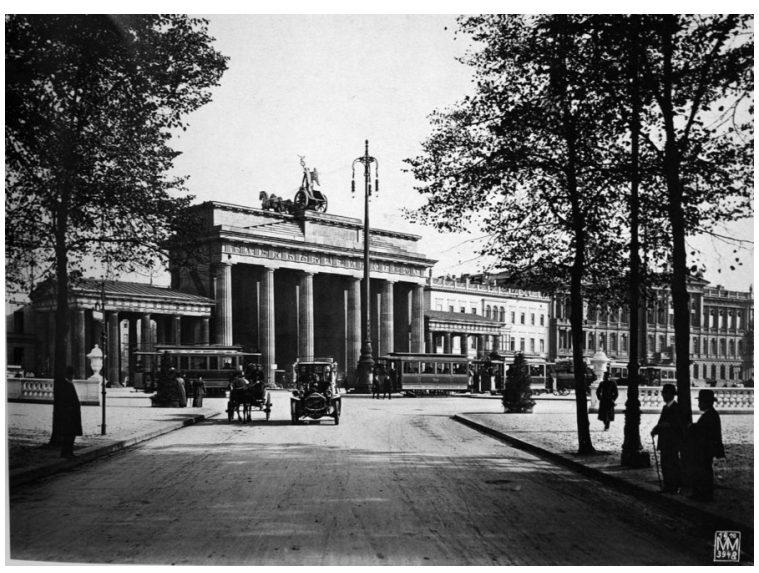

Figura 5. M. Missmann, vista hacia la Puerta de Brandenburgo desde la Friedensallee, Berlín 1910

ya ni la avenida ni las estatuas que la adornaban por ambos lados; y el Ángel de la Victoria, al que conducia en otros tiempos, se ha desplazado a otro lugar. ¿Qué queda entonces del pasado? Tendemos a pensar que lo único que realmente queda de él, es el recuerdo.

\section{LA IMAGEN Y EL TIEMPO DEL RECUERDO}

Partiendo del hecho de que no hay recuerdo sin olvido, sea fortuito o sea forzado, queremos destacar en lo siguiente la conexión que hay entre recuerdo e imagen. En muchas ocasiones el recuerdo evoca imágenes en la persona particular. Las imágenes, sin embargo, también se pueden independizar del recuerdo individual y con ello de la persona que, al recordar, las evocó. Es precisamente este hecho el que hace posible que el recuerdo vaya pasando, mediante la imagen transmitida, de una persona a otra y de una generación a la siguiente.

Como muestra Walter Benjamin en su ensayo El narrador, la transmisión de recuerdos, imágenes e historias se realizaba en otros tiempos mediante un procedimiento esencialmente arraigado en el presente: la narración oral que pasaba de boca en boca formando un único universo que cubría todo con un velo aurático y mantenía así las cosas más pequeñas y las más grandes, las más cercanas y las más lejanas en una unidad que transcendía los dualismos tanto ontológicos como epis-

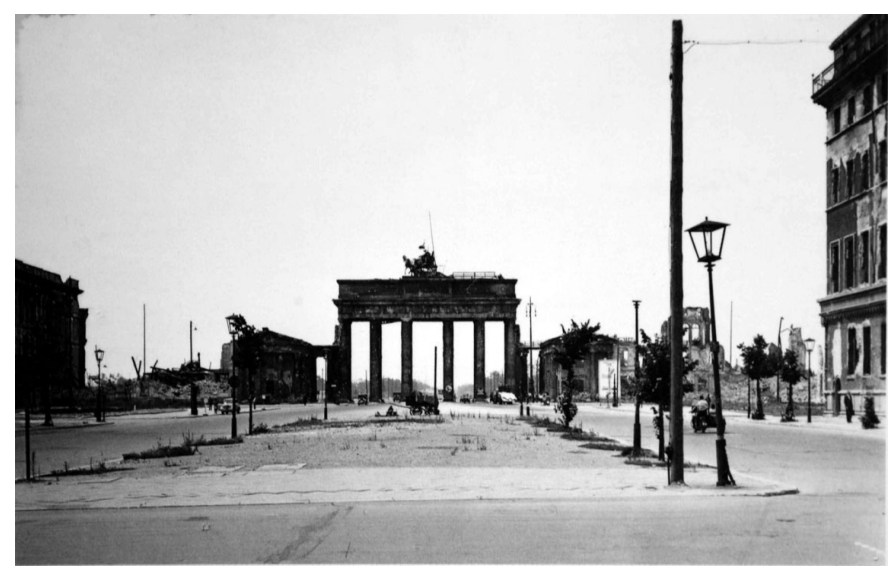

Figura 6. La Puerta de Brandenburgo, Berlín, tras la Segunda Guerra Mundial.

temológicos² (Benjamin, 1991a, 111-134). Esos tiempos, sin embargo, han pasado. La modernidad no es una época propicia para cubrir las cosas con un velo aurático que sugiere la experiencia única de una lejanía cercana. La fragmentación ha superado la totalidad. En su ensayo sobre La obra de arte en la época de su reproductibilidad técnica Benjamin confronta el mago de entonces -el pintor que observaba "una distancia natural para con su dato" para crear una imagen "total"- con el cirujano de hoy, el cámara que "se adentra hondo en la textura de los datos" creando una imagen fragmentada cuyas partes deben unirse según una nueva ley (Benjamin, 1973a, 43). Cine y fotografía representan para Benjamin los medios artísticos que mejor corresponden a la actualidad caracterizada por el deseo de acercar las cosas a las masas y superar el ideal de lo irrepetible, lo singular ("Einmaliges"). En ese sentido, Benjamin afirma en su Pequeña historia de la fotografía:

Día a día cobra una vigencia más irrecusable la necesidad de adueñarse del objeto en la proximidad más cercana, en la imagen o más bien en la copia [Abbild]. Y resulta innegable que la copia, tal y como la disponen las revistas ilustradas y los noticiarios, se distingue de la imagen. La singularidad ["Einmaligkeit", A. M. R.] y la duración están tan estrechamente imbricadas en ésta como la fugacidad y la posible repetición lo están en aquélla (Benjamin, 1973b, 75).

Ahora bien, ¿qué significa la aparición de las nuevas técnicas reproductivas para el conocimiento y recuerdo de la 
ciudad? Con la aparición de la fotografía en el siglo XIX se abre la posibilidad de que las ciudades con sus calles, plazas y monumentos sean conocidas a masas de personas sin limitación espacial. $Y$ aunque no puedan vencer toda limitación temporal, las reproducciones fotográficas pueden transmitir el aspecto de los lugares emblemáticos de la ciudad a las generaciones venideras también en el caso de que se destruyan o desaparezcan sus monumentos y edificios. Eso sí, cuanta más fidelidad se persigue en la fotografia, mayor es el precio que se paga. Pues la copia que trata de mostrar al máximo el aspecto visible de la ciudad y fijarlo para siempre sólo conserva fragmentos congelados del pasado; le falta la dimensión del presente, de un tiempo vivo en el que se compenetran presencia y ausencia. Con ello se obstaculiza un recuerdo activo, a saber, una historia no concluida, abierta a preguntas inesperadas y descubrimientos actuales. Lo dicho nos Ileva a diferenciar dos tipos de fotografía relacionadas con el recuerdo. Uno trata de cerrar y fijar una historia del pasado, el otro busca la historia inconclusa que es tan presente como ausente.

Si aplicamos el término benjaminiano de "copia" (Abbild) a la fotografía, tenemos, por tanto, que hacer una distinción que no aparece en el texto citado. Tenemos que hablar, por un lado, de la reproducción que intenta fijar el pasado como si se tratara de algo que se puede poseer y conservar como tal, y, por otro lado, de la copia que trata de incorporar la presencia y ausencia de un pasado presente, esto es, la chispa que centellea en un instante para desaparecer en el siguiente, dando paso, entre un momento y otro, al pasado en el presente. La diferenciación que acabamos de hacer aparece implícita en las así llamadas Tesis de Benjamin que se publicaron póstumamente bajo el título Sobre el concepto de historia. En este sentido Benjamin afirma en la tesis $V$ :

El verdadero rostro de la historia se aleja al galope. Sólo retenemos el pasado como una imagen que, en el instante mismo en que se deja reconocer, arroja una luz que jamás volverá a verse. "La verdad ya no se nos escapará": estas palabras de Gottfried Keller caracterizan con exactitud, en la imagen de la historia que se hacen los historicistas, el punto por el que pasa el materialismo histórico. Irrecuperable, en efecto, es cualquier imagen del pasado que amenace desaparecer con cada instante presente que, en ella, no se haya dado por aludido3 (Löwy, 2003, 71).
Y en la siguiente tesis VI dice:

Articular históricamente el pasado no significa conocerlo "tal como fue en concreto", sino más bien adueñarse de un recuerdo semejante al que brilla en un instante de peligro. Corresponde al materialismo histórico retener con firmeza una imagen del pasado tal como ésta se impone, de improviso, al sujeto histórico en el momento del peligro [...] (Löwy, 2003, 75).

Aunque Benjamin hable en sus Tesis de "imagen" y no de "copia", está claro que cuando usa en este texto el término de "imagen", no está refiriéndose a la imagen irrepetible, singular, aurática que diferencia, en su Pequeña historia de la fotografía y en su escrito sobre la obra de arte, de la copia, esto es, de la imagen repetible y reproductible. Lo que le interesa en sus Tesis es, más bien, resaltar la diferencia entre la fijación estática mediante una imagen que pretende descubrir el "verdadero" pasado para poseerlo y conservarlo "tal como fue", y la captura al vuelo de un presente en el que repercute el pasado, y a la vez, de un pasado que llega al presente ${ }^{4}$. Con esta diferenciación Benjamin saca a luz dos maneras distintas de relacionarse

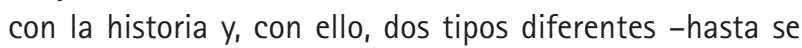
podría decir opuestos- de imágenes del recuerdo y de la memoria. Encontramos el primer tipo en la imagen volcada a una seguridad inmóvil que fija el pasado, el segundo en la imagen atenta al "peligro" que, leyendo las huellas del pasado en el presente, se abre a las condiciones actuales y los acontecimientos inminentes.

No podemos dejar de hacer referencia aquí al "ángel de la historia" que aparece en las Tesis. En la famosa interpretación que Benjamin hace del Angelus Novus de Paul Klee, el ángel de la historia está presenciando la acumulación de los escombros que van quedando en la historia. La situación descrita en la tesis IX, en la que aparece la referencia al cuadro de Klee, rompe con la idea que nos solemos hacer de la linealidad unidireccional del tiempo. En la imaginación cotidiana, la mirada se vuelve hacia atrás cuando se dirige al pasado. Benjamin da la vuelta completa a esta imagen invirtiendo y llevando al absurdo la idea de que "delante" está el futuro y "detrás" el pasado, quedando entremedio el presente, en algún lugar no identificable ni localizable. El ángel de la historia no se vuelve hacia atrás para ver el pasado, pues la cita en alemán dice claramente: "Er hat das Antlitz der Vergangenheit zugewendet" ("Ha dirigido su mirada hacia el pasado") (Benjamin, 1991b, 697). El prefijo 
"zu" del verbo alemán "zuwenden" tiene un sentido que señala hacia adelante 5 . Si Benjamin hubiera querido decir que el ángel se ha vuelto hacia atrás, habria utilizado el verbo "zurückwenden", cuyo prefijo "zurück" significa "atrás". El sentido que apunta hacia adelante se mantiene también en la siguiente frase en la que Benjamin distingue entre lo que ve el ángel y aquello que aparece "ante" nosotros ("vor" uns), y en la que dice que los escombros de la historia son lanzados "delante" de los pies ("vor" die Füße) del ángel:

Alli donde aparece una cadena de acontecimientos ante nosotros, él ve una sola catástrofe que amontona incesantemente escombro sobre escombro lanzándoselos delante de sus pies (Benjamin, 1991b, 697).

En la imagen que presenta Benjamin se concede todo protagonismo al presente, un presente que tiene enfrente un pasado que va creciendo y decayendo continuamente, lo cual implica, a su vez, un constante devenir y desvanecer. ¡Cuántas vueltas se dan en esta imagen! El ángel quiere parar el tiempo, "quiere quedarse" para "despertar a los muertos y recomponer lo que se ha roto" (Benjamin, 1991b, 697). Pero el presente con su pasado y su devenir y desvanecer continuo sigue adelante, lo cual significa, a la vez, que sigue hacia atrás, pues el "futuro" se encuentra detrás del ángel que le "da la espalda" (Benjamin, 1991b, 698). El ángel es llevado contra su voluntad, mediante el vendaval que llega del paraíso, hacia atrás, esto es, hacia el futuro que queda completamente fuera del campo visual. Mas, ¿qué es ese futuro que no se puede ver? Al revelarnos que el viento, esa fuerza ciega e incontrolable que nos empuja hacia una dirección indeseada, no es otra cosa que el progreso, Benjamin muestra que el futuro, en la concepción común del tiempo lineal progresivo, no es más que una mera promesa vacía refutada constantemente por la historia. Pero para verlo hay que salirse fuera de la lógica del tiempo lineal y sus promesas de progreso. Hay que dar la vuelta, como el ángel de la historia, y mirar hacia aquello que se tiene enfrente, delante de los ojos; ahí está todo lo que el tiempo ofrece: sus apariciones y desapariciones ${ }^{6}$.

\section{EL ROSTRO DE LA CIUDAD}

Nada nos impide aplicar la distinción que hemos hecho entre la imagen que fija el pasado y aquélla que se abre al presente al caso específico de la imagen reproducida y reproductible. Vamos a considerar en lo siguiente con más detención la reproducción que intenta fijar el pasado "tal como fue en concreto". A este tipo de copia pertenecen las primeras fotografías que intentan reproducir los monumentos de la ciudad para conservar la memoria de los mismos. En relación con la copia que intenta facilitar un "fiel" recuerdo del pasado podemos recordar las palabras de Döblin en el texto que hemos citado antes, donde decía que cada pieza individual del vestuario del legado "se deja fotografiar bien" indicando con ello la íntima relación que existe entre el monumento y (cierto tipo de) fotografía.

Conviene hacer aqui algunas observaciones sobre los inicios de la fotografía de arquitectura, en los que Francia y Alemania juegan un papel importante. Los encontramos en Francia en el año 1837, cuando se creó allí la "Commission des Monuments historiques" cuya función era registrar todos los monumentos de interés artístico e histórico y ocuparse de la conservación de los monumentos típicos para las épocas y su sucesión, para que "de esta manera se conserven para todos los tiempos las obras modelo que deben ser fotografiadas por arquitectos franceses"7 (Wolf, 2002, 350). Dicha comisión editó una obra titulada Archives de la comisión des monuments historiques. Poco después, entre 1840 y 1844, Noel Paymal Lerebours editó en París las Excursions daguerriennes. Vues et monuments les plus remarquables du globe en las que aparecian monumentos artísticos daguerrotipificados en forma de litografías. En su primera edición ya se utilizó en Francia el medio de la fotografía como muestra ilustrativa para la propagación de monumentos.

En Prusia, por su lado, se creó en 1833 el cargo de conservador para monumentos artísticos. Uno de los primeros conservadores fue el señor von Quast al que se dirigió el arquitecto Albrecht Meydenbauer para presentarle su método de medición aplicable a grandes edificios: la fotogrametría ${ }^{8}$. La nueva técnica fue bien recibida y se practicaría a partir de 1883. Dos años después, Meydenbauer fundó la Institución Real de Fotogrametría y empezó a crear un archivo de fotografías arquitectónicas de monumentos. Con el tiempo se fueron creando grandes tomos de fotografía cuyos ejemplares se exponían en el Ministerio de Cultura y los conservadores de las provincias prusianas. En todos los trabajos que se realizaron en la institución de Meydenbauer se pretendía lograr una reproducción que 
pudiera sustituir la contemplación directa de los monumentos en su lugar original. Los métodos y las directrices que se seguian para cumplir este objetivo se reflejaban también en la fotografía arquitectónica alemana que surgió fuera de la institución y que floreció en las últimas décadas del XIX y las primeras del XX. En todos los centros alemanes de fotografía del siglo XIX, en Múnich, Hamburgo, Dresde y Berlín, se abrieron estudios donde se producian fotografías arquitectónicas para postales, ilustraciones de libros, decoraciones caseras, objetos de colección o materiales documentales para instituciones públicas, la industria o el comercio.

Volvamos a nuestra distinción anterior entre la fotografía que fija el pasado y aquella que se abre al presente. Podemos diferenciar ahora la foto que intenta fijar y conservar un fragmento del pasado o bien algo que, para las generaciones venideras, pertenecerá al pasado, de la fotografía en la que penetran mutuamente pasado, presente y futuro, presencia y ausencia, aparición y desaparición. El primer tipo lo encontramos representado en las fotografías que hacía la Institución Real de Fotogrametría y los fotógrafos de arquitectura de finales del XIX y principios del XX. Fotografías de este tipo se centran en un determinado objeto, lo aíslan o lo destacan con la intención de "acercarlo" al contemplador, mejor dicho, a masas de contemplado- res, estén donde estén. De esta manera, los monumentos reproducidos no sólo pueden sobrevivir y perdurar en el tiempo, sino que, disminuidos y aplanados, pueden viajar también en el espacio y llegar a miles de personas. En lo que se refiere a la relación de estas fotografías con la historia se observa que cobran paradójicamente un aire más ahistórico cuanto mayor sea su empeño de fijar y conservar la historia.

A este respecto es interesante comparar las fotos realizadas por los profesionales de la fotografía arquitectónica que acabamos de mencionar con las imágenes de Berlín que tomó el autor del libro para el que escribió Döblin la introducción que citamos al principio (figs. 7-16). El libro es uno de los dos tomos de fotografía publicados en 1928 bajo el lema "El rostro de la ciudad", que pretendian retratar dos grandes ciudades europeas, Paris y Berlín, tal y como eran en su momento, esto es, en los años veinte. El fotógrafo encargado era el barón austriaco Mario von Bucovich, nacido en 1884 y afincado entre 1926 y 1930 en Berlín. Aparte de las fotos, ambos libros contenían textos breves de escritores importantes: el de Berlín lo introducía Alfred Döblin y el de París contaba con un texto de Paul Morand ${ }^{10}$. Los tomos representativos de un formato de $22 \times 30$ centímetros con más de 250 imágenes realizadas por un solo fotógrafo suponían en aquel entonces, al menos para Berlín,

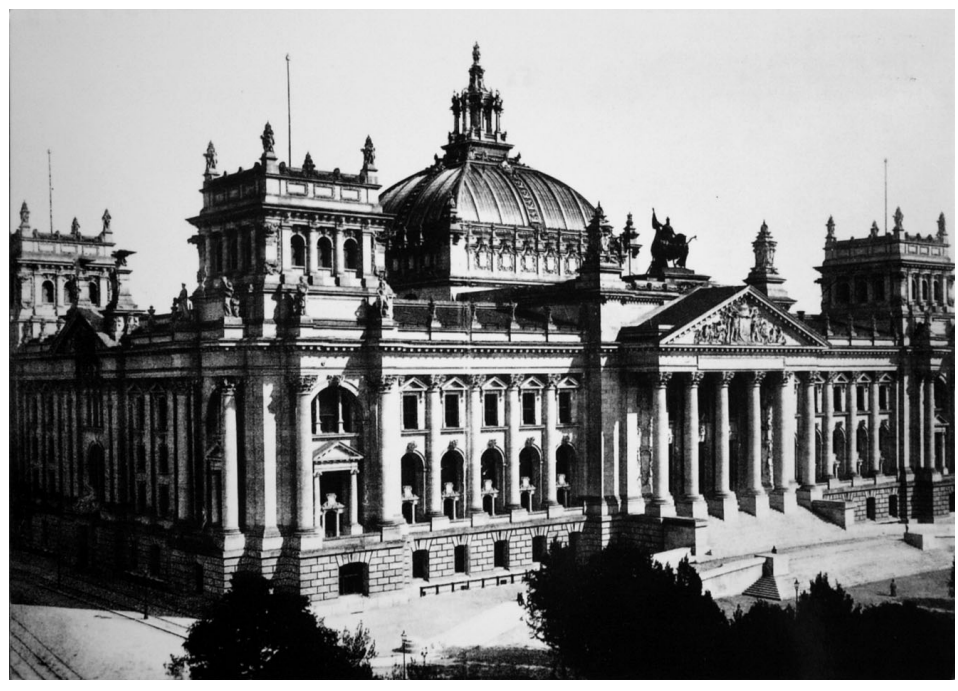

Figura 7. Postal del edificio del Parlamento (Reichstag) al terminarse de construir en 1894.

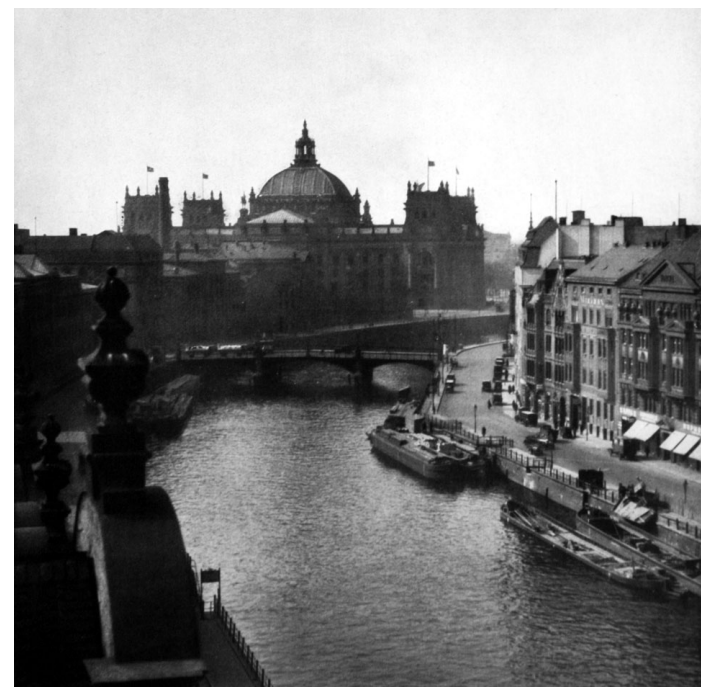

Figura 8. Mario v. Bucovich, vista al Reichstag desde el río Spree, 1928 


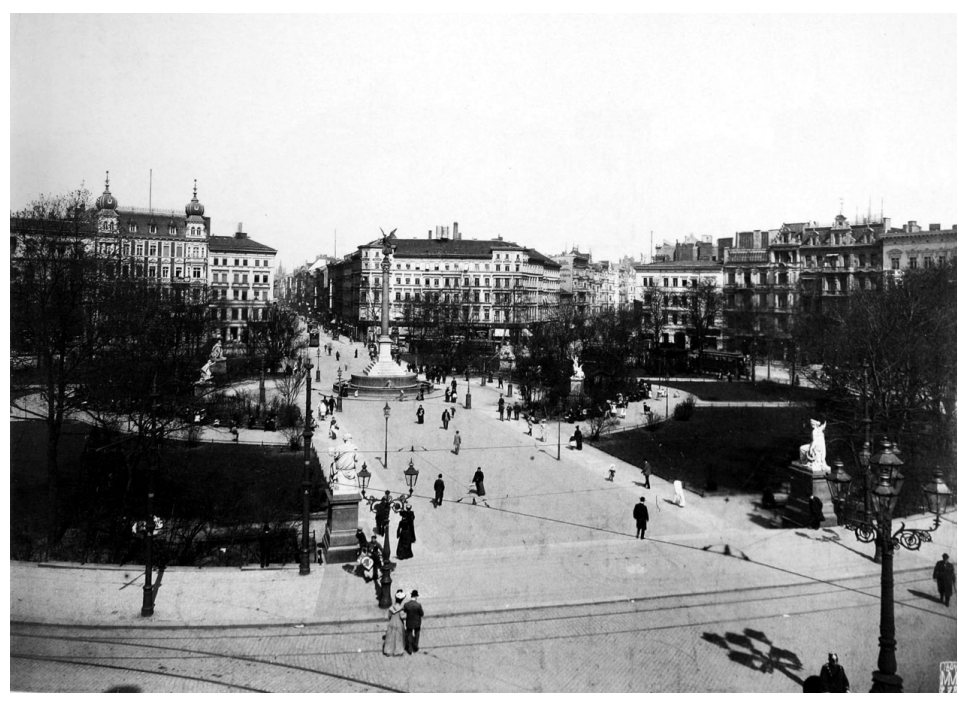

Figura 9. M. Missmann, vista de la Plaza Belle-Alliance, 1904.

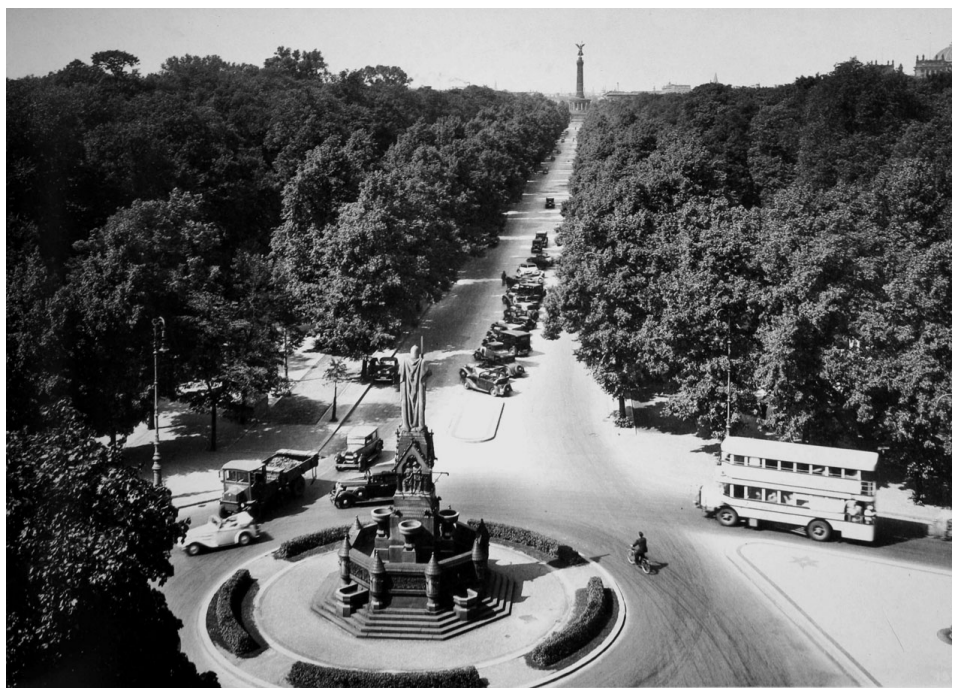

Figura 11. M. Missmann, Plaza de Kemper y Siegesallee (Avenida de la Victoria).

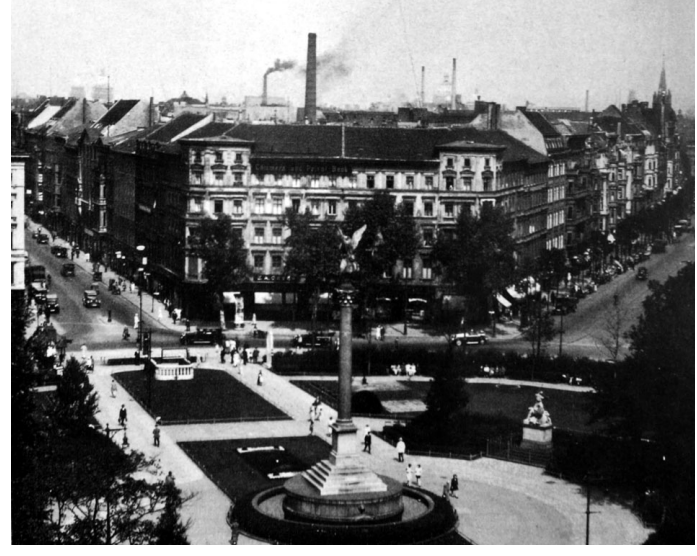

Figura 10. M. v. Bucovich, vista de la Plaza BelleAlliance, 1928.

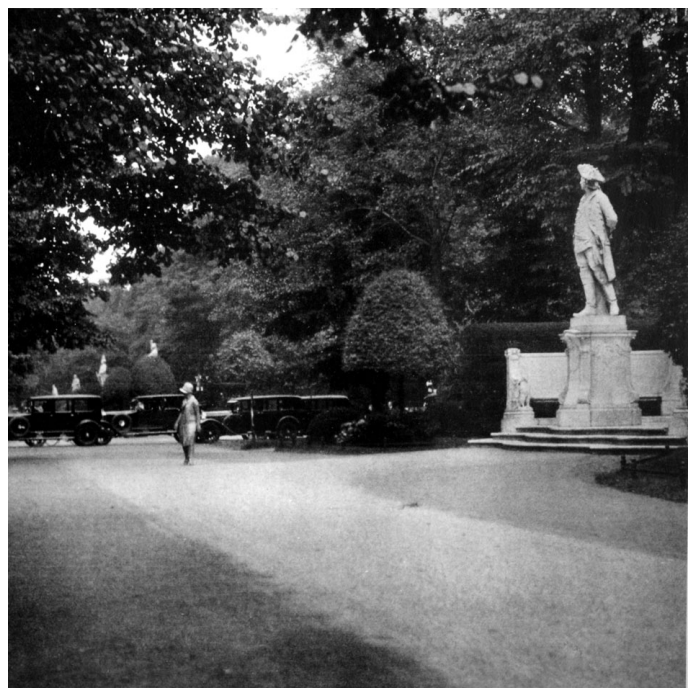

Figura 12. M. v. Bucovich, vista de la Siegesallee, 1928. una novedad. En la capital alemana no había habido hasta ese momento ningún libro de fotografías de Berlín que hubieran sido tomadas expresamente para ser publicadas como libro. En el contexto de la tendencia de la "nueva fotografia" influenciada por la escuela del Bauhaus, Bucovich intentó mostrar la ciudad desde perspectivas nuevas que se diferenciaban de las vistas y reglas establecidas para la fotografía arquitectónica alrededor de 1900. El trabajo de Bucovich, que mereció comentarios elogiosos por parte de Benjamin, puede haberse inspirado también en la película Berlín. Sinfonía de una ciudad de Walter Ruttmann que se había estrenado en septiembre de $1927^{11}$. 


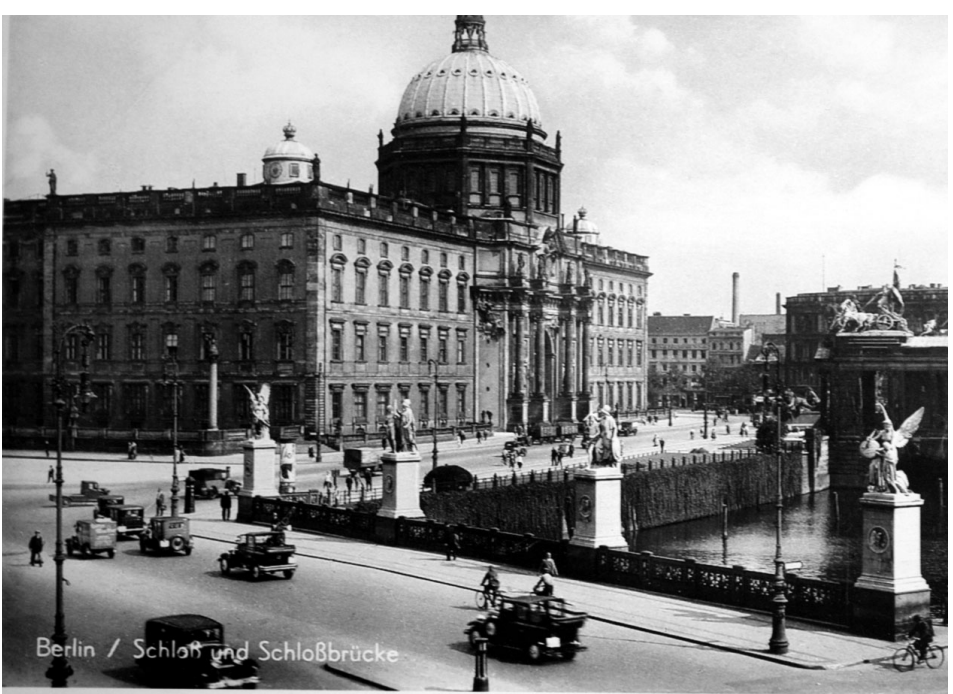

Figura 13. Postal del Palacio de los Hohenzoller y del Puente del Palacio, hacia 1930, Berlín.

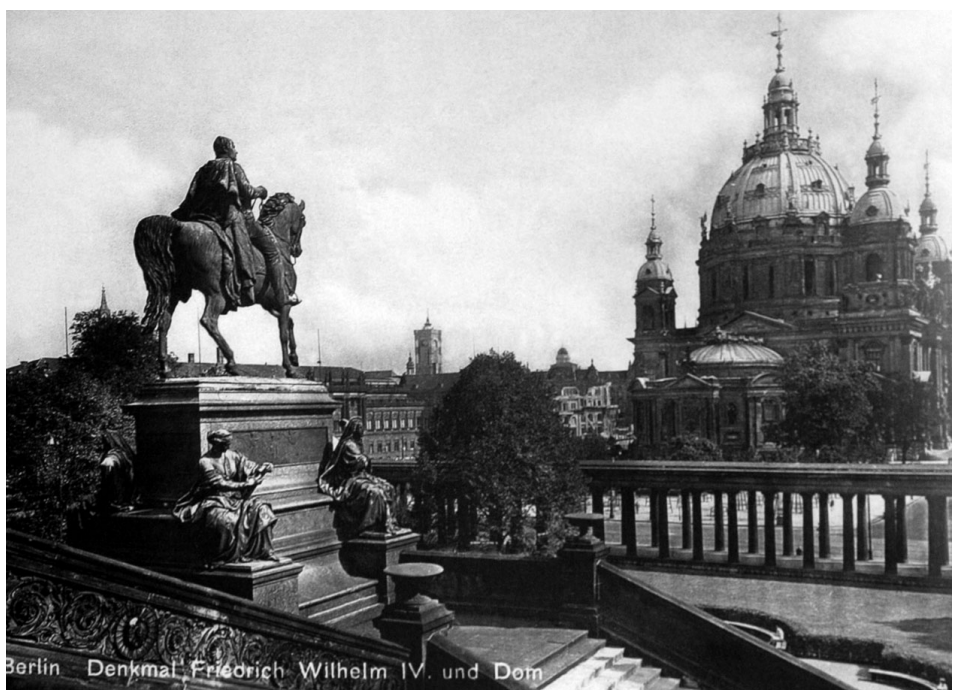

Figura 15. Postal del monumento a Federico Guillermo IV y de la Catedral, Berlín.

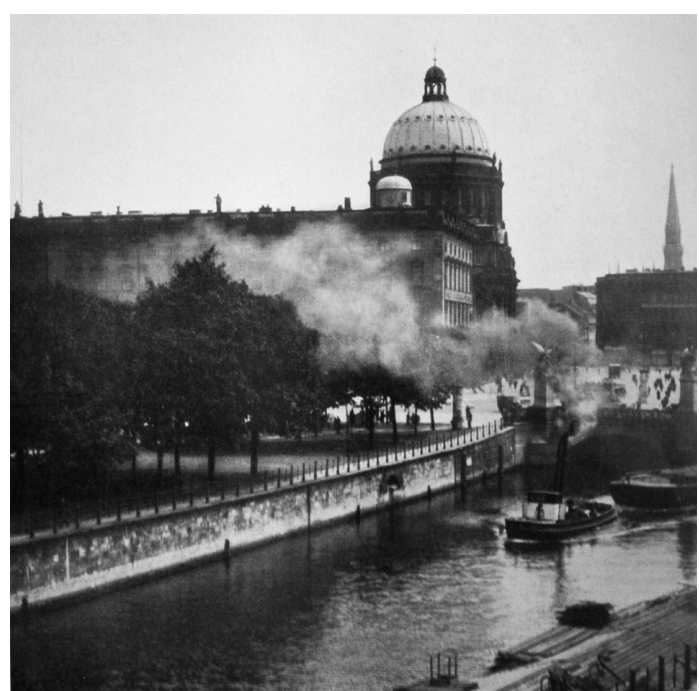

Figura 14. M. v. Bucovich, Palacio de los Hohenzoller y Puente del Palacio, 1928.

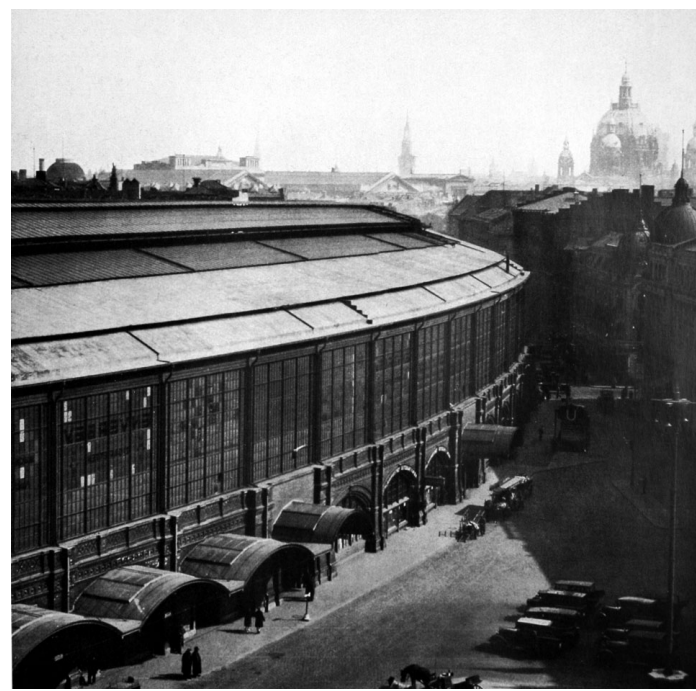

Figura 16. M. v. Bucovich, Estación de Friedrichstraße, al fondo: vista de la Catedral, 1928.
El libro de Berlín al que nos queremos referir aquí, no se compone sólo de fotografías de plazas emblemáticas, edificios y monumentos conocidos de la ciudad. Al contrario, el "vestuario de legado", como había apellidado Döblin esos lugares, forma la parte más pequeña del libro, y cuando aparece, se muestra casi siempre en pers- pectivas y vistas poco representativas, fragmentadas 0 cortadas, dejando como protagonista la dinámica actual de la ciudad. Comparando algunas fotografías suyas de monumentos conocidos con fotos de los mismos monumentos realizados por otros fotógrafos profesionales de la época, uno se percata de que Bucovich intenta integrar

ARBOR Vol. 187747 enero-febrero [2011] 143-168 ISSN: 0210-1963 
los monumentos y los lugares emblemáticos del pasado en el presente y hacerlos dialogar con la vida actual de Berlín.

En su libro de fotografias de Berlín, Bucovich muestra las diferentes caras que tiene la dinámica de la ciudad a finales de los años 20. Se ve gente corriendo para llegar a tiempo al barco de vapor en la ribera de Brandenburgo, chimeneas de fábricas echando humo desde la ribera del río Spree en la zona trabajadora del este o por encima de la Columna de la Paz en la Plaza Belle-Alliance (fig. 10). También el gigantesco Palacio de los Hohenzoller está inundado de humo (fig. 14), esta vez de un barco de vapor que pasa por delante. $Y$ vuelve a salir vapor, ahora de la locomotora de un tren que, al paso de su ritmo cotidiano, sale entre el solemne museo de KaiserFriedrich y el de Pergamon en la zona monumental de la Isla de los Museos en el centro de Berlín para continuar a los barrios obreros del este. Siguiendo las vías, calles, los ríos y canales llegamos a lugares en los que divisamos a lo lejos otros monumentos y edificios emblemáticos de la ciudad (figs. 8, 14, 16). En algunos casos el monumento al que conduce la vía ha quedado fuera de la vista, teniendo que producirse en la mera imaginación, como

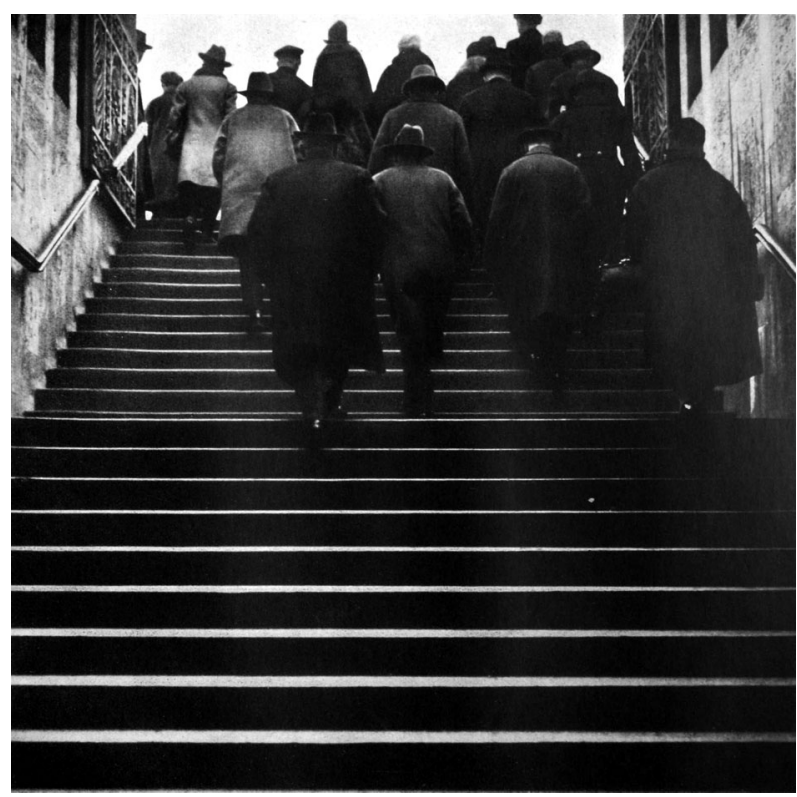

Figura 17. M. v. Bucovich, masas saliendo del metro, Berlín, 1928. ocurre en la foto de la Siegesallee que, como sabemos, lleva a la Columna de la Victoria, monumento ausente en la imagen, aunque se presenta en la imaginación si "miramos" hacia abajo imitando la postura del paseante y de las estatuas, como nos propone Bucovich de manera humoristica (fig. 12). Se ofrecen perspectivas intimas de entradas, ventanas y fachadas de casitas al lado de fotografías aéreas del gigantesco complejo del palacio y del aeropuerto de Tempelhof, tiendas pequeñas con transeúntes y potenciales clientes y avenidas elegantes de barrios burgueses, mercados y los grandes almacenes de la época, la publicidad con sus grandes logos y letras en los edificios que empiezan a inundar las ciudades en esa época, y vistas nocturnas de la ciudad con sus luces y su publicidad luminosa, arquitectura moderna de la época al lado de edificios emblemáticos más antiguos, instantáneas de gente con las tareas más variopintas y con oficios tanto antiguos como modernos: por un lado cocheros, por otro obreros de la construcción, trabajadores en mataderos, vendedores ambulantes de salchichas o libros, desocupados jugando a las cartas, masas anónimas subiendo las escaleras de la boca del metro, cruzando la plaza de la estación del Zoológico, buscando cobijo de la lluvia, sombras en la calle... (figs. 17-20).

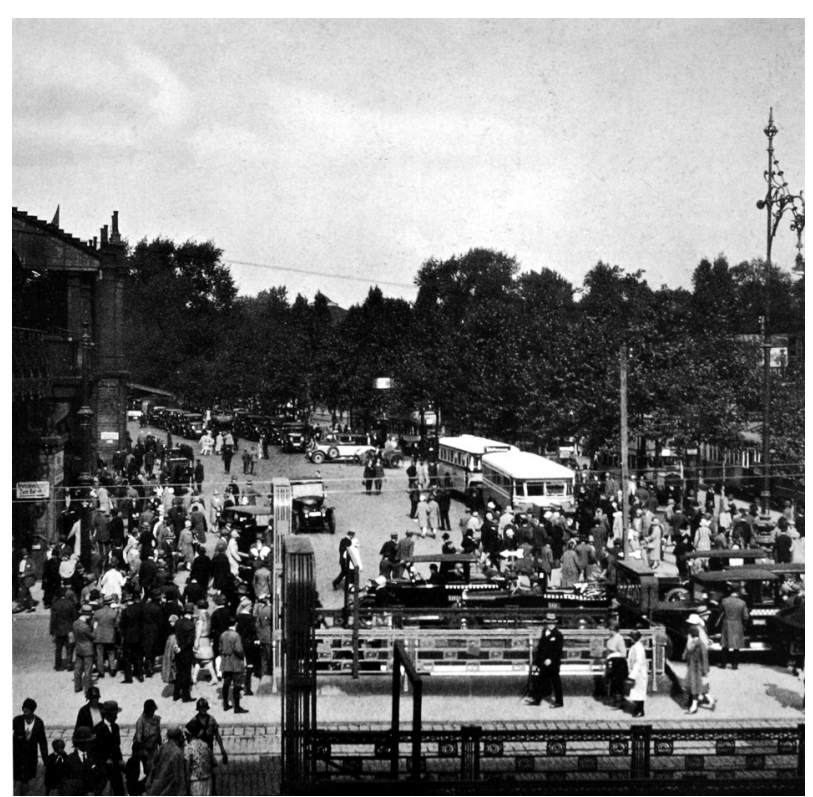

Figura 18. M. v. Bucovich, en la plaza de la estación del Zoológico, Berlín, 1928. 


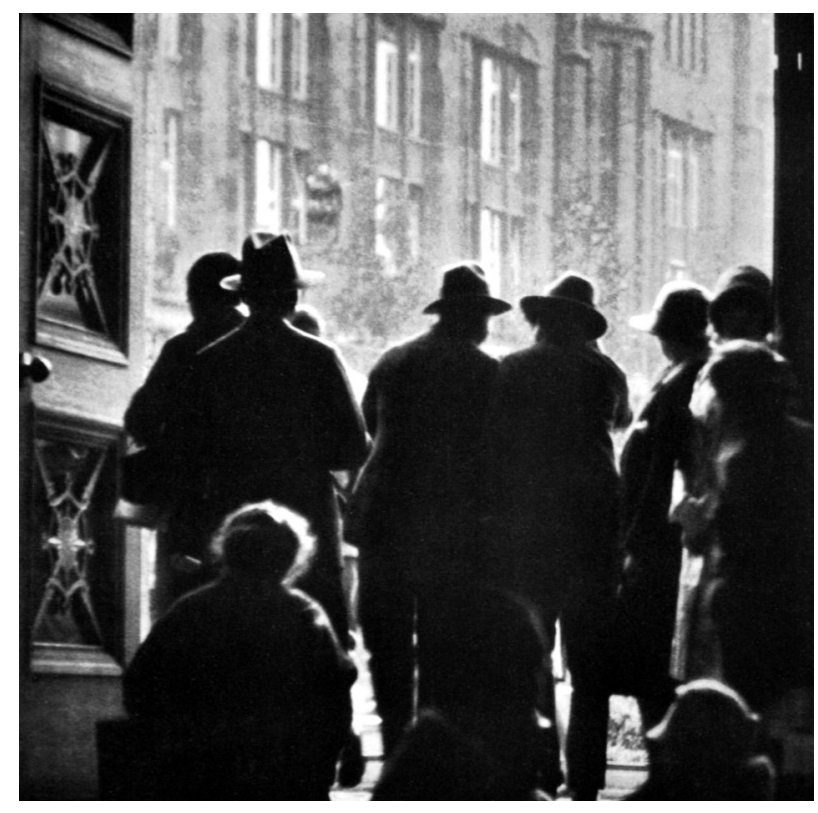

Figura 19. M. v. Bucovich, gente buscando cobijo de la lluvia, Berlín, 1928, en: v. Bucovich (nota 1).

\section{LA CIUDAD INVISIBLE}

En su texto introductorio al libro de Bucovich, Döblin habla de las masas. Resalta que, en el momento en que lo escribe, Berlín tiene 4 millones de habitantes y dispone de 20 estaciones de trenes de largo recorrido. El interés de Döblin apunta, pues, al presente, esto es, a la vida actual de la ciudad y sus habitantes, y entre estos últimos, a los trabajadores y pequeños empleados, aquello que representa la masa: la masa que llega y circula cada día por la ciudad, que se mueve por las calles, viaja en los medios de transporte y vive en los así llamados "cuarteles de alquiler" ("Mietskasernen") con "fachadas vacías" como resalta Döblin. Según el escritor, estos edificios de los vivientes, que abundan en la ciudad, no se diferencian entre ellos; sólo se distinguen de las casas de los muertos, a saber, de los monumentos característicos que son contemplados por los turistas, porque su fin es ser contemplados. Mas, como resalta, sólo el conjunto ("das Ganze") tiene rostro, no una pequeña pieza individual:

Nadie puede hablar de un trozo de Berlín o mostrar con razón una sola construcción arquitectónica (a no ser que fuera un cuartel de alquiler multiplicado por 100.000). Sólo

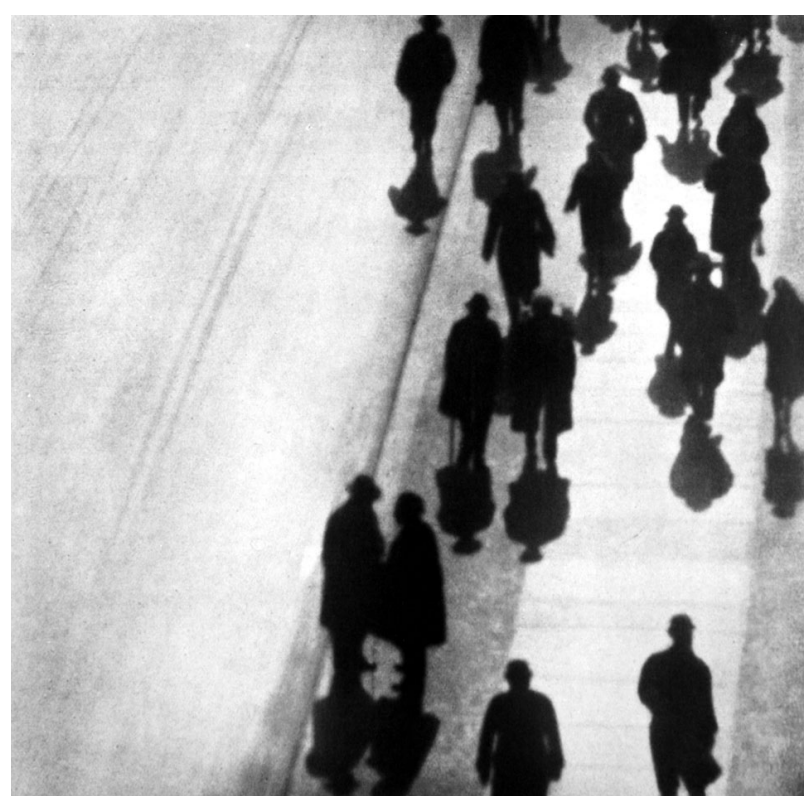

Figura 20. M. v. Bucovich, sombras en la calle, Berlín, 1928, en: v. Bucovich (nota 1).

el conjunto tiene un rostro y un sentido: el de una ciudad moderna fuerte y sobria, de una colonia de masas ["Massensiedlung"] productora (von Bucovich, 1992, s.p.).

Si pensamos en la vida, las preocupaciones, actividades y viviendas de las personas de las que se componen las masas urbanas de las que habla Döblin -en su mayoría miembros de la clase baja: obreros, pequeños empleados, pero también masas de parados- puede que las fotografías de Bucovich nos resulten todavía demasiado elegantes y pulidas. Esta impresión se refuerza cuando comparamos sus fotos con las que hizo Heinrich Zille a principios del siglo XX de sus compatriotas berlineses (figs. 21-28). Desde luego, las fotos de Zille, un dibujante que se convertiría en los años veinte en uno de los grafistas satíricos más populares de Alemania, no estaban destinadas como tales a un público en general; de hecho pasaron décadas tras su muerte antes de que se conocieran en público ${ }^{12}$. Su finalidad no era, pues, la publicación en un elegante libro de fotografías destinado a mostrar a los forasteros y turistas, pero también a los berlineses mismos, el rostro actual de la capital alemana. Más bien tenían un uso particular; servían como modelo para las litografías y los dibujos satíricos 


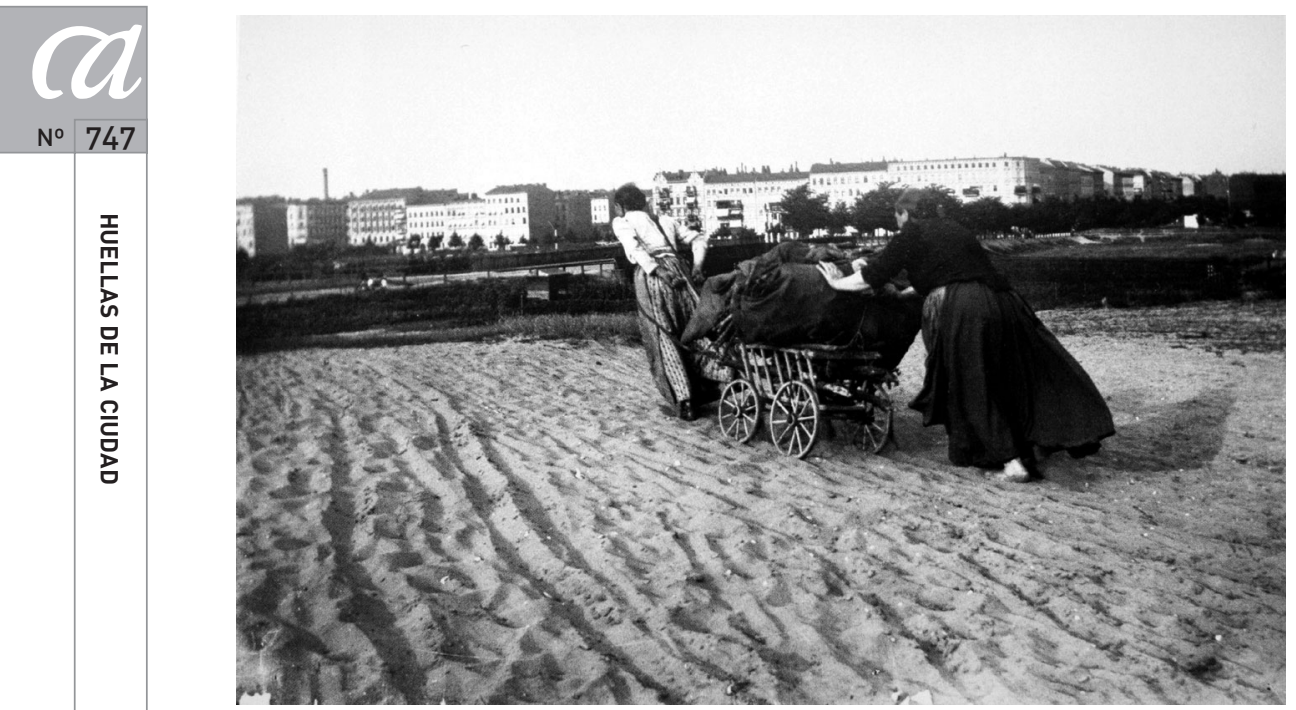

Figura 21. H. Zille, recolectoras de chasca, Berlín, 1898.
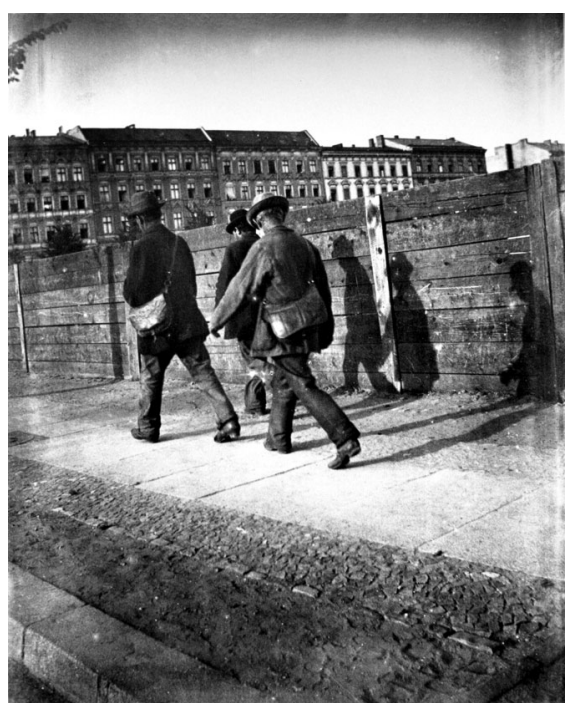

Figura 22. H. Zille, tres hombres volviendo a casa, Berlín, 1898.

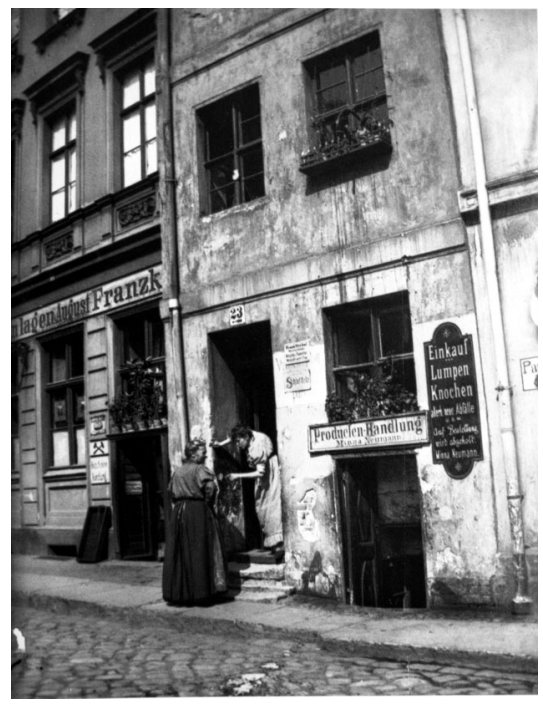

Figura 23. H. Zille, Parochialstraße 23 y 24, Berlín, 1902/1903.

con los que Zille, comprometido con la clase social de la que provenía, buscaba reflejar la vida cotidiana de las clases bajas, de todas esas multitudes trabajadoras que empezaban a inundar las grandes ciudades y a vivir en los "cuarteles de alquiler" que abundaban en la ciudad, aquellas viviendas que, según Döblin, no se diferenciaban entre ellas. En las fotografías de Zille los monumentos

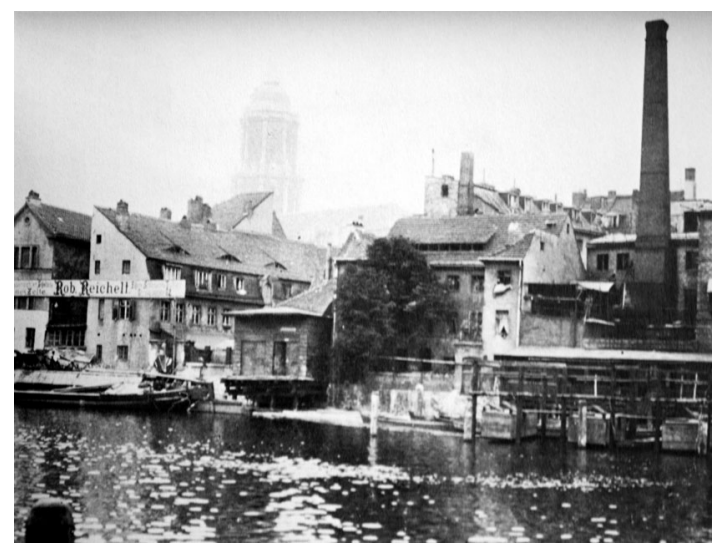

Figura 24. H. Zille, ribera del Spree, al fondo: torre del Stadthaus, Berlín, 1910.

y edificios emblemáticos de Berlín ceden el paso a un presente en continuo movimiento en el que predominan las ocupaciones y preocupaciones básicas de la vida urbana. Los monumentos aparecen raramente, y cuando lo hacen, se convierten en meros espectros que ya sólo se vislumbran a lo lejos (fig. 24) o bien abandonan su inmovilidad y solemnidad habitual (fig. 25). 


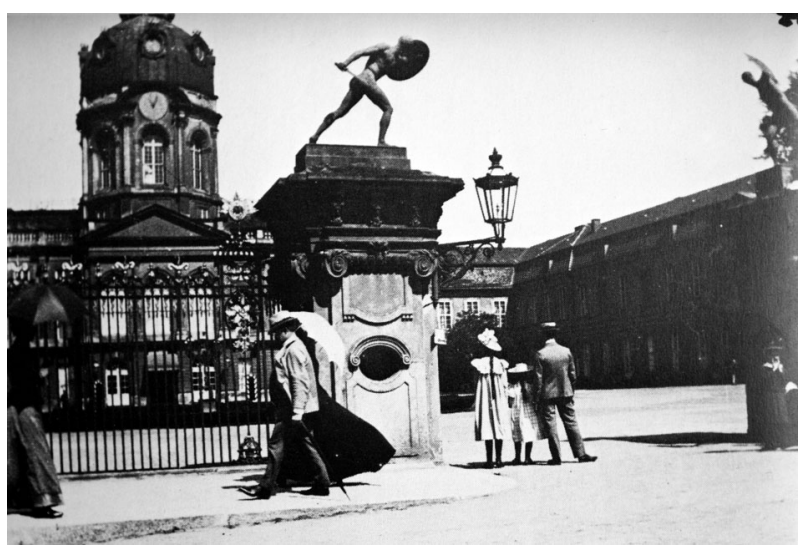

Figura 25. H. Zille, en la puerta del Palacio de Charlottenburg, Berlín.

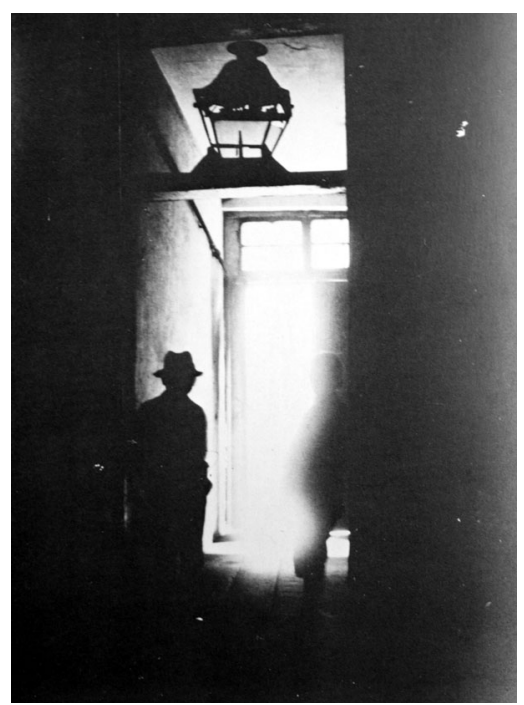

Figura 26. H. Zille, sombra en una casa, Berlín, hacia 1890

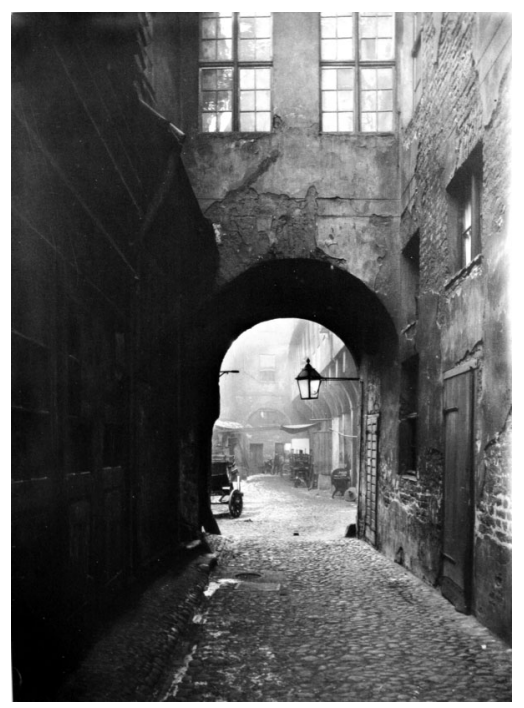

Figura 28. H. Zille, “Krögel”, Berlín, 1896/1897.

Figura 27. H. Zille, esquina de una casa y muro en el "Krögel", Berlín, 1902.

Volvamos tras estas imágenes fugaces captadas por Zille a los comentarios de Döblin sobre el "rostro" de la ciudad. Lo que hace ver Döblin es el dilema al que lleva la relación entre el ver y el conocer. El hecho de que podamos ver algo -un edificio, una plaza, una columna, un puente- hace posible 0 al menos facilita que podamos conocer y reconocer algo. Así, el forastero que haya tenido ocasión de ver la Puerta de Brandenburgo, la Columna de la Victoria, la Avenida Unter den Linden, Sansoussi y algunos monumentos conocidos más de Berlín, parece tener el derecho de decir que conoce hasta cierto punto la capital alemana. No en vano, los monumentos que reconoce y asocia con la ciudad aparecen en los circuitos turísticos como estaciones obligatorias de la visita de la ciudad. Con esta autoridad se 
reproducen una y otra vez: en fotografías, postales, libros y guías de la ciudad.

La íntima relación entre el monumento y su reproducción fotográfica es prácticamente inseparable en el caso de los símbolos de la ciudad, como pueden ser la Puerta de Brandenburgo en Berlín o la fuente de Cibeles en Madrid. El monumento y más aún el símbolo de la ciudad necesita ser reproducido, lo cual quiere decir en primer lugar: fotografiado. En el imaginario cotidiano, el conocimiento de una ciudad no se puede separar de sus monumentos más emblemáticos y a la vez de la reproducción fotográfica de los mismos. Por eso, desde el punto de vista cotidiano hace falta ver una ciudad para conocerla; y verla signifi$c a$, dentro de esta misma lógica, reconocer determinados monumentos emblemáticos que se han reproducido miles de veces. ¿Dónde se encuentra aquí el dilema?

Döblin no dice que uno cree ver la ciudad cuando contempla sus monumentos. Afirma que uno la ve, la conoce y reconoce, o al menos parte de ella. Lo que uno ve y reconoce es algo conocido, que existe también en otros sitios, algo ya visto, y en cuanto que lo es, más que al presente fugaz, pertenece a una historia fijada, y como tal, muerta. Lo que se presenta ante la vista como lo característico de una ciudad -la reproducción de monumentos sacados de su contexto histórico y entorno actual- no constituye, por tanto, el rostro vivo y presente de la ciudad. Pues éste está en constante movimiento: aparece desapareciendo. El dilema está en que lo visible de la ciudad es lo conocido y con ello lo reconocible. Mas, para ser reconocible, tiene que haberse fijado, y como algo fijado, pertenece al pasado, a un pasado inmovilizado. Por eso, el ver que reconoce lleva al pasado. El que, en cambio, quiere conocer la ciudad actual, una entidad que se compone de miles de vidas, tiene que atenerse, por tanto, también a lo que rehúsa la demanda de una mirada que reclama visibilidad; tiene que estar atento a lo que se sustrae de lo directamente visible. Por tanto, si es verdad que "conocer" en el sentido de re-conocer algo del pasado apunta a las cosas que son visibles, hay que añadir que conocer en el sentido de aventurarse en los momentos del presente, un presente que conlleva pasado y futuro, requiere un intuir cosas que se sustraen a la vista.

La vida palpitante de la ciudad se sustrae y a la vez se manifiesta de mil maneras. Pero no por fotografiar cada monumento, cada calle y cada esquina, tiene que asomarse necesariamente la vida y el presente de una ciudad. Incluso si fuera posible reproducir todos los lugares y puntos de la ciudad y componer luego a partir de todos esos fragmentos una especie de puzzle gigantesco no se habría conseguido que se asomara el rostro de la ciudad, pues éste no se muestra a simple vista, aunque sea multiplicado por mil. Hay que intentar, pues, atrapar al vuelo lo que se sustrae a la vista. Hay que atenerse a aquello que, estando presente, lleva a sus espaldas, sin saberlo, lo ausente, aquello que apareciendo desaparece. En una palabra: Hay que atrapar las huellas. ¿Pero las huellas de qué?

\section{EN busca de huelLas}

Si supiéramos a qué o a quién pertenecen las huellas que hay que atrapar, si supiéramos exactamente adónde llevan aquellas presuntas huellas que creemos haber descubierto, no necesitaríamos adentrarnos en el laberinto de la gran ciudad. ¿Mas, qué es, en fin, la huella?

La huella, en principio, es algo que guarda, o al menos promete guardar, una historia, entendiendo "historia" tanto en el sentido histórico-temporal como en el sentido de la "narración". En este contexto hay que distinguir dos tipos de huellas, admitiendo que entre los dos extremos hay múltiples mezclas posibles. Los dos tipos fundamentales son las huellas intencionales y las no intencionales.

Huellas intencionales son configuraciones deliberadas que se prestan a ser conocidas, reproducidas y difundidas, puesto que llevan directamente a una historia concreta, descifrable y fácilmente transportable. A este tipo de huellas pertenecen los monumentos característicos de la ciudad que se encuentran reproducidos de manera aislada en incontables fotografías, postales y objetos de souvenir. Los monumentos que se prestan a ser reproducidos son huellas que la historia oficial ha dejado con toda intención a las generaciones posteriores para que asocien unas determinadas épocas, unos acontecimientos y personajes con ciertas ideas. En general, las huellas intencionales se imponen en el sentido de que señalan claramente la dirección que debe tomar el pensamiento y la imaginación de la persona que se topa con ellas; favorecen la repetición, costumbre y vuelta sobre lo mismo. En su impertinente 
intencionalidad cierran la puerta al descubrimiento y enigma, la incertidumbre y duda fértil. En su pura visibilidad, estas huellas se olvidan de lo oculto, invisible, inefable aunque presente, de manera que el ver excesivo se torna, finalmente, en impedimento, en ceguera.

La huella no intencional, en cambio, es una aparición que centellea, que promete y a la vez oculta. No se deja reproducir de manera aislada, puesto que abre un espacio no delimitado, en gran parte desconocido. A diferencia de la huella intencional que en su constante repetición se impone para finalmente cegarnos, la huella no intencional no se impone, aunque sí nos mira. $Y$ necesitamos que nos mire, pues como resalta Benjamin en su texto "El regreso del flaneûr", citando al escritor Franz Hessel: "Sólo vemos lo que nos mira"13. La huella, sin embargo, sólo mira si se le da una oportunidad. $Y$ eso requiere una determinada actitud y disposición. Antes se dijo que el rostro presente de la ciudad sólo se atrapa al vuelo. Ahora bien, ¿qué tipo de disposición o actitud permite atrapar huellas fugaces?

Quedándonos con el mundo filosófico e imaginario de Benjamin, con quien queremos reflexionar a continuación sobre la búsqueda de huellas no intencionales en la ciudad, el personaje más apto es el flaneûr, aquel personaje, producto del París del siglo XIX, que, sin objetivo ni destino, deambula por las calles y preferentemente por los pasajes de la ciudad sumergiéndose de vez en cuando entre las masas, pero sin perder su ritmo individual, lento, dispuesto siempre a pararse y dejarse atrapar por una huella que le mira. A diferencia de las masas que surgen en el XIX y se mueven aceleradas por las ciudades, el flanêur anda despacio y capta rápido ${ }^{14}$. Ese callejeo distendido y a la vez atento le convierte, según Benjamin, en un "detective contra su voluntad". En el París del Segundo Imperio en Baudelaire afirma Benjamin lo siguiente con respecto al flaneûr-detective:

Atrapa las cosas al vuelo; con ello puede soñarse cerca del artista. Todo el mundo elogia el lápiz rápido del dibujante. $\mathrm{A}$ Balzac le gustaría ligar la capacidad artística con un captar rápido. Sagacidad criminalistica unida a la afable negligencia del flanêur proporciona la proyección de "Mohicans de Paris" de Dumas. Su héroe decide partir en busca de aventuras siguiendo un trozo de papel que suelta al juego de los vientos. Cualquiera sea la huella que persigue el flanêur, siempre le va a conducir a un crimen (Benjamin, 1991d, 543).
Igual que el artista moderno que intenta captar al vuelo las cosas y los momentos fugaces, el flanêur es una figura que vive al margen de las masas, incluso cuando se inserta en la muchedumbre. Pues se resiste a adoptar el paso veloz de la multitud. Y ese quedarse atrás le hace ver huellas, huellas que conducen al crimen.

La asociación del flanêur con huellas que conducen, indican o hacen presentir un crimen es frecuente en Benjamin. En un principio esta asociación choca. ¿Por qué la huella tiene que llevar a un crimen? ¿Por qué no puede conducir a una simple historia?

Mas, ¿cómo ha de entenderse el crimen? ¿Cuál es su lugar y su función en la gran ciudad? El crimen es algo que irrumpe en la maquinaria de la metrópoli; detiene su curso continuo y le arranca la fachada de la automatización y de lo previsible. En su lugar aparece lo discontinuo, lo desconocido, la duda, el choque, el abismo... Si se entiende el crimen de esta manera, la huella que el flanêur atrapa al vuelo con "sagacidad criminalística", aquella huella que lleva al crimen, le dispensa de la falsa ilusión tanto de la ciudad-máquina en la que se mueven, perfectamente insertadas, las masas anónimas siguiendo el tiempo lineal con su lógica causal, como de la ciudad-monumento fijada, inmóvil, insertada en una repetición constante. Aquello que se interpreta como huella de un crimen abre, con la sospecha que lo acompaña, de pronto en el presente una dimensión del pasado, esto es, una historia abierta, sin resolver, y con ello también la dimensión del futuro inmediato: la demanda de buscar vías nuevas para poder construir una historia desconocida ${ }^{15}$.

Desde luego es difícil hallar las huellas de las historias abiertas que se esconden, camufladas, en el presente. Como las huellas del crimen encubierto desaparecen entre la muchedumbre de la metrópoli. Para descubrir huellas con sus respectivas historias hace falta, pues, bajar, ir hacia abajo. Esto es precisamente lo que hace el antes citado escritor Franz Hessel, autor del libro Pasear en Berlín, que, en opinión de Benjamin, recuperó el "teatro imprevisible del flaneo" siguiendo el recuerdo como "musa" que va bajando por las calles (Benjamin, 1991d, 194).

El ir hacia abajo es la actitud contraria a la contemplación inmóvil, desde abajo, que exigen las grandes estatuas ecuestres que el último emperador prusiano-alemán, Guillermo II, sembró en honor a los reyes prusianos y sobre todo a sí mismo por 
toda Alemania. En su texto El regreso del flanêur, escrito con motivo de la publicación del libro de Hessel, Benjamin tiene la esperanza de que los berlineses hayan cambiado y que su "problemático orgullo fundacional de la capital" haya cedido a la afición a Berlín como patria (Benjamin, 1991d, 194). Los monumentos de los reyes no sirven para los que miran hacia abajo ni tampoco para los niños. Pues éstos no se dejan manipular tan fácilmente; en vez de alzar la vista y reproducir en la mente la idea gloriosa que el monumento quiere transmitir, empiezan a entretenerse con detalles. Quizás se detienen más con el zócalo que con la figura victoriosa que se levanta sobre él, y finalmente lo llenan todo de vida, sueños y deseos. A este respecto es interesante señalar cómo comienza Benjamin sus recuerdos de infancia de un Berlín de principios del siglo XX. El lema que antepone a la obra es una alusión a uno de los monumentos más emblemáticos de la capital alemana. Ya lo conocemos: se trata de la "Columna de la Victoria" o "Columna Triunfal"16. Mas, ¿cómo se refiere Benjamin a ella?

\section{0, Columna Triunfal tostada}

Con azúcar de invierno de los días de la infancia ${ }^{17}$.

(Benjamin, 1991e, 236)

La solemne columna triunfal, creada para ser admirada, contemplada y reproducida a distancia, se convierte en algo no sólo tangible, sino incluso comestible ${ }^{18}$. En el recuerdo de Benjamin obtiene, pues, el color marrón y el dulce sabor de las pastas que niños y adultos comen en Alemania en tiempos navideños ${ }^{19}$.

Pero volvamos a la huella fugaz que abre la sospecha del crimen. El mero recelo que suscita este tipo de huella no sólo despierta la atención y hace reparar en detalles 0 aspectos que antes no se habían visto, sino que lleva también a tejer historias a partir de esos detalles, ir en busca de descubrimientos, encontrar y producir conexiones inusuales.

De nuevo en el libro Infancia en Berlín hacia 1900 nos percatamos de que es el niño quien conoce la promesa, esto es, el enorme potencial significativo que se halla en la huella captada al vuelo. En el texto Accidentes y crímenes de ese libro dice Benjamin:

La ciudad me los prometía cada mañana de nuevo y por la noche quedaba debiéndomelos. Cuando ocurrían, desaparecian tan pronto como yo llegaba al lugar de los sucesos, al igual que los dioses que sólo disponen de un instante para los mortales. Una vitrina robada, una casa de la que habían sacado un muerto, el lugar de la vía donde cayera el caballo, me plantaba alli para saciarme de la fugaz esencia que los sucesos dejaron, pero en el mismo instante se fue esfumándose, dispersada y llevada por la multitud de curiosos que acabaron de disgregarse (Benjamin, 1990, 118).

Benjamin nos muestra un niño que siente fascinación por esa "fugaz esencia" que dejan los sucesos: las huellas casuales que se presentan en un instante para esfumarse en el siguiente. Perplejo ante el hecho de que aparecen tan súbitamente como desaparecen, el niño se queda con la duda y la sospecha. La misma sensación le provocan unos vehículos "muy extraños" que "guardaban su secreto con la misma tenacidad que los carros de los gitanos" (Benjamin, 1990, 118). Lo que le hace fantasear al niño son los barrotes de hierro que protegian las ventanas y que le llevaban a sospechar que lo que transportaban esos coches no era otra cosa que "malhechores y criminales". Sólo años después, ya de adulto, sabe que se trataba de unos coches que transportaban expedientes. Los misteriosos vehículos con los presuntos criminales, los puentes y ríos con sus supuestas historias de suicidios, los posibles sucesos no muestran su cara al niño. Como resalta Benjamin en el mismo texto,

[T]odos estos actos se mantenían tan lejos de mí como los guerreros de piedra del Museo de Pergamon (Benjamin, 1991e, 292, trad. de la cita: A. M. R.. ${ }^{20}$.

No importa que los actos queden tan lejos del niño como las estatuas gigantescas y los demás monumentos de la ciudad. Lo importante es seguir buscando, atrapando y vislumbrando huellas casuales para seguir tejiendo historias. ¿Quién sabe qué historias oscuras, peticiones, injusticias o ilusiones estaban, de hecho, guardadas en los expedientes que se transportaban en los vehículos? ¿Cuántos asuntos pendientes quedaron encerrados para siempre tras aquellos barrotes de hierro, en aquellas apariciones fugaces que el niño captaba al vuelo interpretándolas como huellas de sucesos que había que descubrir e indagar.

También el artista busca y teje historias abiertas. No es, desde luego, el caso del fotógrafo que persigue una historia concluida, un trozo del pasado que se puede fijar y conservar "tal como es". Pero sí concierne el fotógrafo artístico que se aventura en el presente, descubre y muestra huellas casuales, huellas que, como aquéllas relacionadas con la 
sospecha de un crimen, hacen vislumbrar lo ausente en el presente. Así, en su Pequeña historia de la fotografía, Benjamin dice de las fotografías de Eugène Atget (figs. 29-36) al que el Gobierno francés encargó fotografiar el viejo Paris a finales del XIX:

No en balde se ha comparado ciertas fotos de Atget con las de un lugar del crimen (Benjamin, 1973b, 82).

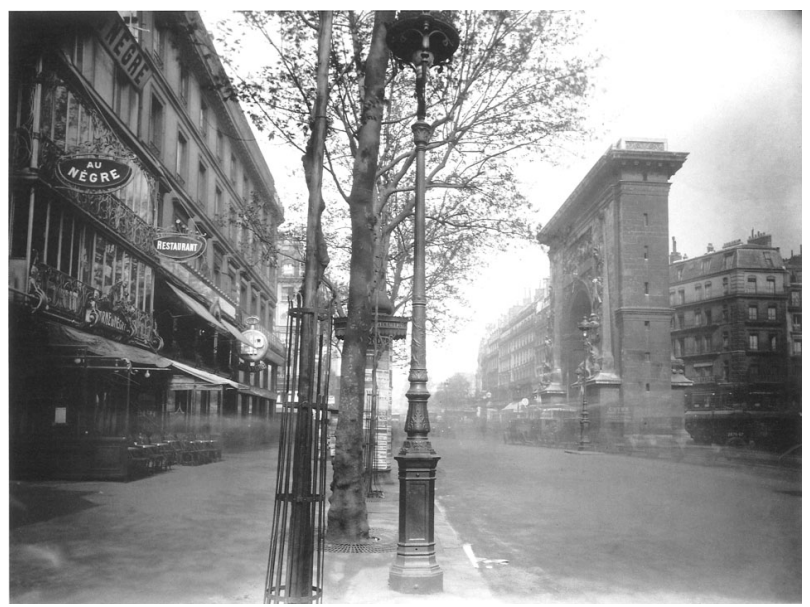

Figura 29. E. Atget, Boulevard Saint-Denis, París, 1926

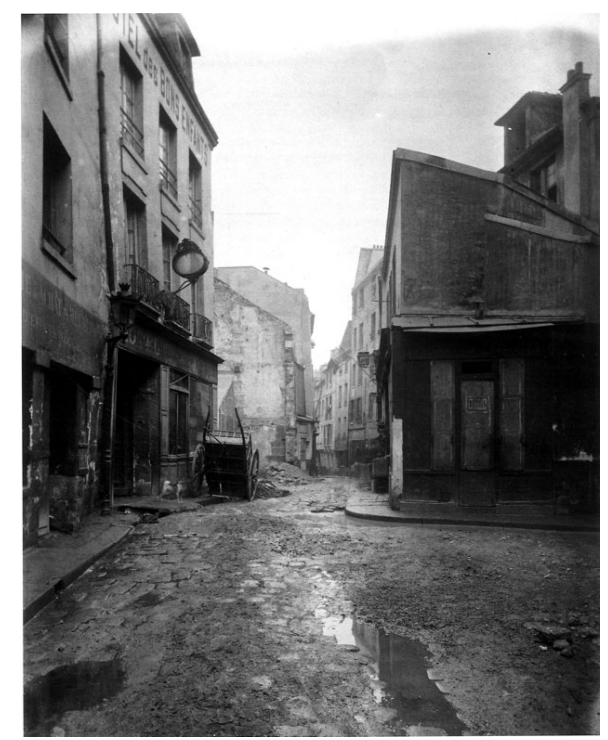

Figura 31. E. Atget, Calle Saint-Médard, París, 1899.
Y sigue diciendo con respecto a todos los lugares de la ciudad y sus fotógrafos:

¿Pero no es cada rincón de nuestras ciudades un lugar del crimen?; ¿no es un criminal cada transeúnte? ¿No debe el fotógrafo -descendiente del augur y del arúspice- descubrir la culpa en sus imágenes y señalar al culpable? (Benjamin, 1973b, 82).

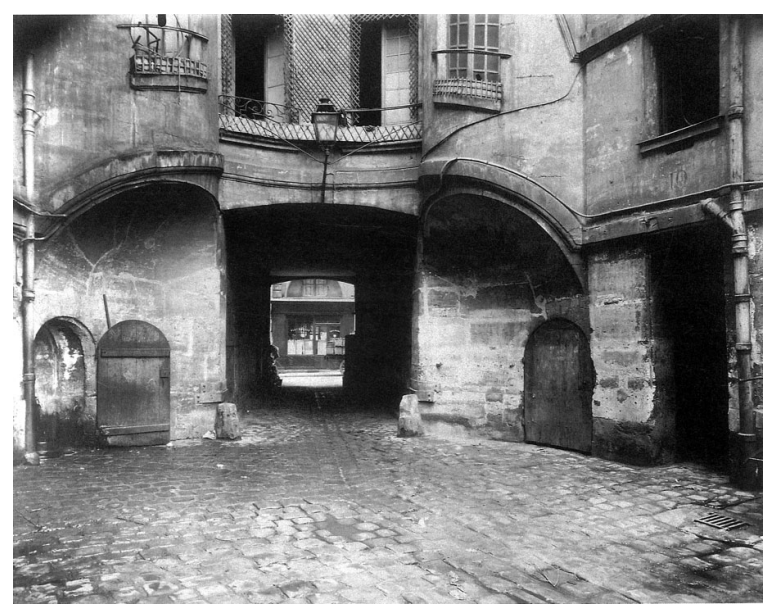

Figura 30. E. Atget, Cour du Dragon, París, 1913.

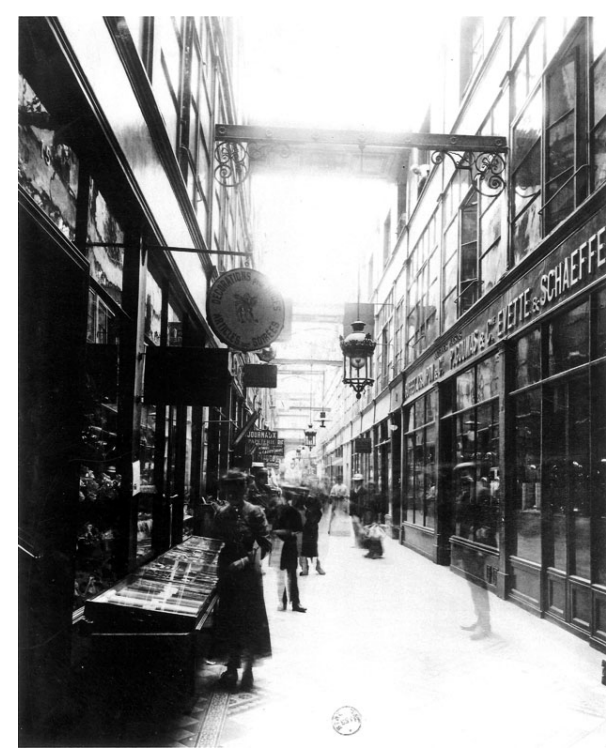

Figura 32. E. Atget, Passage du grand Cerf, París, 1907.

ARBOR Vol. 187747 enero-febrero [2011] 143-168 ISSN: 0210-1963

(2) 


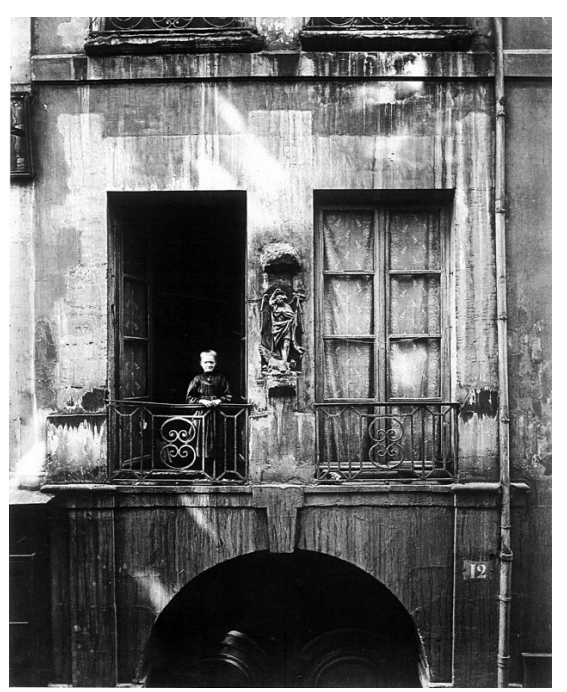

Figura 33. E. Atget, Collège de Chanac, París, 1900.

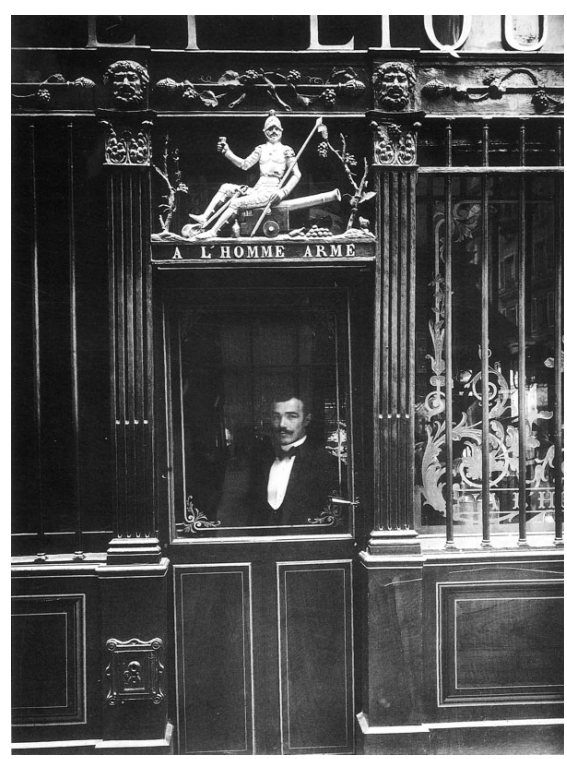

Figura 35. Café "A l'Homme Armé", París, 1900

Mas, ¿cómo puede descubrir el fotógrafo esa "culpa", esto es, esas huellas fugaces que conducen al crimen? Atget, por ejemplo, pasaba, como afirma Benjamin, casi siempre

de largo "ante las grandes vistas y ante las que se llaman señales caracteristicas [Wahrzeichen]"; no asi ante una larga fila de hormas de zapatos; ni tampoco ante los patios pari-

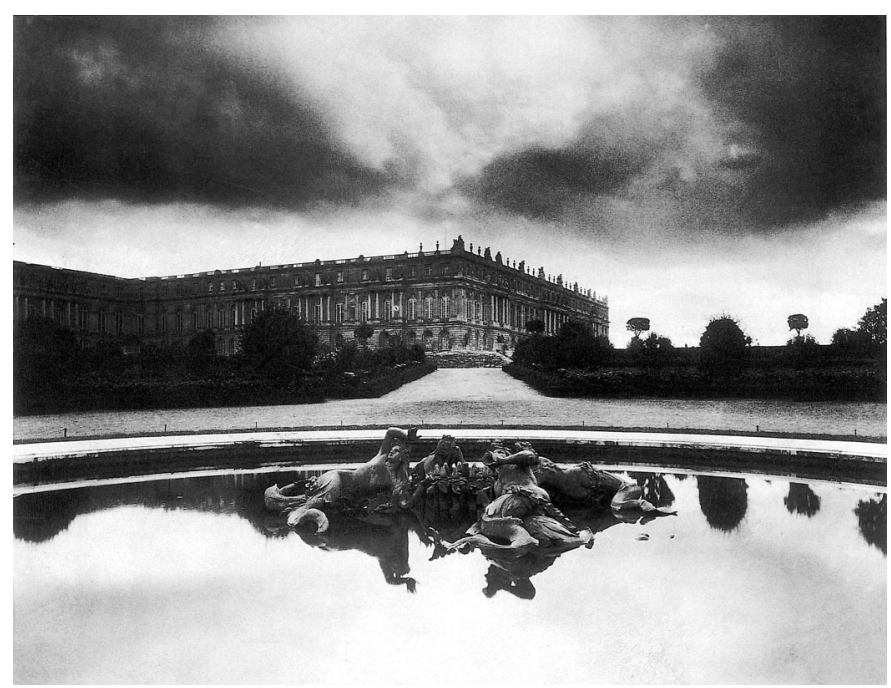

Figura 34. E. Atget, Versailles, París, 1903.

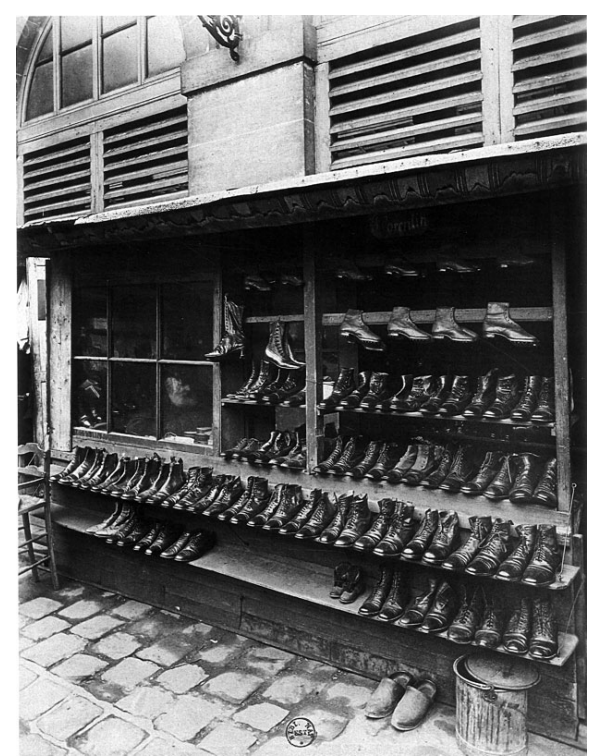

Figura 36. Marché des Carmes, París 1910-11.

sinos en los que desde la noche hasta la mañana se enfilan los carros de mano; ni ante las mesas todavía empantanadas y platos sin ordenar que están allí por cientos a la misma hora; ni ante el bordel de la calle..., número 5 , cifra ésta que aparece gigantesca en cuatro sitios diversos de la fachada. Pero es curioso que casi todas estas imágenes estén vacías. Vacía la Porte d'Arcueil de los paseos de ronda, vacías las 
fastuosas escaleras, vacíos los patios, vacías las terrazas de los cafés, vacía, como es debido, la Place du Tertre (Benja$\min , 1973 b, 75-76)$.

Si Benjamin hubiera conocido las fotografías de Zille, habría descubierto en muchas de sus instantáneas los mismos momentos que percibe en las imágenes de Atget: escenarios vacíos que parecen ocultar una historia inaudita y levantan la sospecha de un crimen (figs. 26-28) ${ }^{21}$. Ahora bien, ¿cuál es el potencial íntimo que Benjamin ve en las fotografías de Atget que rompen con el canon clásico de la vista y reproducción de los lugares de la ciudad? Según Benjamin, la fotografía de Atget prepara un

extrañamiento salutifero entre hombre y mundo entorno. A la mirada políticamente educada le deja libre el campo en que todas las intimidades favorecen la clarificación del detalle (Benjamin, 1973b, 76).

En La obra de arte en la época de su reproductibilidad técnica Benjamin resalta con respecto a las fotografías de Atget la activación del contemplador que ya no se puede dejar caer en una contemplación libre y pasiva. Al contrario, el receptor que se incomoda ante las imágenes de calles vacias fotografiadas por Atget siente que tiene que buscar por sí mismo el camino que le llevan a éstas. Es esta activación del espectador la que supera el valor cultual que dominaba en otros tiempos e intentaba seducir y fascinar al espectador. Con respecto a Atget y las calles parisinas que fotografió, Benjamin afirma que

[c]on mucha razón se ha dicho de él que las fotografió como si fuesen el lugar del crimen. Porque también éste está vacío y se le fotografía a causa de los indicios. Con Atget comienzan las placas fotográficas a convertirse en pruebas en el proceso histórico. $Y$ asi es como se forma su secreta significación histórica. Exigen una recepción en un sentido determinado. La contemplación de vuelos propios no resulta muy adecuada. Puesto que inquietan hasta tal punto a quien las mira, que para ir hacia ellas siente tener que buscar un determinado camino (Benjamin, 1973b, 31).

El shock, desconcierto, la incomodidad, inquietud y curiosidad son para Benjamin vías fértiles que llevan a intuir, dentro de lo visible, lo invisible, aquello que aparece desapareciendo: historias abiertas con sus promesas y peligros, que no se presentan de manera directa ni se dejan captar una vez por todas. El fotógrafo que atrapa huellas fugaces hace entrever historias, misterios y destinos de la ciudad y sus habitantes, que no se pueden fijar de manera univoca y estática. Pueden ser estrategias distintas las que llevan a ello. Así, por ejemplo, se pueden hacer montajes que proporcionan una superposición de perspectivas y con ello una simultaneidad de dimensiones espacio-temporales, como hizo el fotógrafo alemán Umbo en los años veinte (fig. 37). Otro fotógrafo, el ruso Alexander Ródchenko, empleaba perspectivas asombrosas, inusuales y hasta abismales, del Moscú de los años veinte y treinta, en las que se vislumbra una sociedad insertada en un importante cambio, una realidad en completo movimiento (fig. 38). El alemán Herbert List, a su vez, presentaba imágenes que cuestionan la solemnidad de los monumentos y obstaculizan su visibilidad para dar paso a la duda y la sospecha, pero también a una mirada humoristica liberadora (figs. 39, 40).

\section{Reflexiones finales}

Más que abrir una puerta del pasado, y desde luego más que del presente, las huellas intencionales, y en especial los monumentos conmemorativos creados para ser contemplados de manera aislada, fomentan una actitud en la que predomina la repetición y el hábito.

Si Döblin hablaba de los monumentos como el legado de los muertos, no sólo se refería a los difuntos de otras épocas, sino a la ausencia de vida que hay en ellos. Y como hemos visto, su insistente visibilidad obstaculiza una actitud propicia para el descubrimiento. El que busca la vida y sus historias abiertas - pasadas y presentes- tendrá que atrapar los momentos fugaces, las huellas casuales: en plazas vacías, en monumentos 0 en otros lugares, del tipo que sean. Como un detective en el lugar del crimen, tendrá que buscar las huellas discretas o secretas de historias desconocidas.

El que busca la dinámica actual de la ciudad tiene que atrapar las huellas de un presente-pasado-futuro que se escapa entre las apariencias visibles y reconocibles. Las historias ocultas no se pueden poseer ni preparar para la mera reproducción; sólo se puede atrapar al vuelo lo que se 
está escapando continuamente, lo que está en constante movimiento, pero no en una sola dirección sino en infinitas direcciones. Pues el tiempo que trae y se lleva las historias no es lineal. El fotógrafo consciente de la falsa ilusión de la causalidad lineal busca las huellas en instantáneas de apariciones fugaces, en sombras, reflejos, apariencias ambiguas, calles vacías y escenas chocantes, en perspectivas sorprendentes o vistas aparentemente insignificantes. Hay muchas maneras en las que puede atrapar o intentar atrapar las huellas del presente, pasado y futuro de la ciudad y sus personajes.

Mas, después de todo, ¿dónde está el rostro de la ciudad? 0 dicho con Benjamin: ¿Cuál es la culpa en las imágenes que el fotógrafo debe descubrir, quién el culpable al que se debe señalar? En el caso del retrato de la ciudad el culpable no es un criminal individual, no es ninguna persona, sino más bien aquello que produce la dinámica de la ciudad, aquello -perteneciente al presente y proveniente del pasado- que es responsable de un determinado tipo de convivencia de múltiples seres, de un estado de conciencia general, de la productividad y los quehaceres de los hombres que forman, juntos y por separado, el fundamento y engranaje de la ciudad, del ritmo y de las múltiples direcciones hacia las que se mueve la metrópoli. El "culpable" puede ser una determinada ideología que predomina en una época y un lugar, como aquélla que ha ido abriéndose camino en el siglo XIX para pisar fuerte en el siglo XX: la ideología del progreso de la humanidad asociada, sin más, con la del progreso técnico. Es una ideología que convierte al hombre individual en una pieza anónima dentro de una gigantesca maquinaria que en su automatización y anonimato puede ser utilizada por los que toman el timón no sólo para fines productivos, sino también destructivos.

El fotógrafo que busca las historias abiertas, vigentes en el presente, trata de evitar la fijación estática, la inmovilización de la huella que descubre. Intenta hacer hablar - via negationis- las huellas casuales y convertir huellas intencionales, como los monumentos y las imágenes conocidas de la ciudad, en apariciones fugaces, dotarlas de un significado dinámico y sacarlas de su inmovilidad, su atemporalidad estática, de la mera repetición. Si lo logra, puede que aparezca en un momento fugaz el rostro de la ciudad, ese sustrato de tantas historias desconocidas, escondidas entre las masas.

\section{NOTAS}

Recibido: 2 de diciembre de 2010

Aceptado: 23 de diciembre de 2010
1 Este artículo ha surgido de una investigación perteneciente a los proyectos Memoria cultural e identidades fronterizas: entre la construcción narrativa y el giro icónico, referencia: FFI2008-05054-C02-01 y Filosofía después del Holocausto: vigencia de sus lógicas perversas, referencia: FFI2009-09368. Quiero agradecer la buena colaboración con el Prof. Ricardo Pinilla en el curso "Los espacios de la memoria en la obra de Walter Benjamin" que impartimos juntos en el año 2009 en la Universidad P. de Comillas y que me proporcionó mucha inspiración para los temas tratados en este artículo.

2 Sobre esta unidad evocada por la narración, que abre un escenario de la memoria completamente distinto al que pueda abrir, p. ej., un archivo, museo o monumento, véase el ensayo de Bernhard Lypp, presentado por primera vez como conferencia en el curso al que se hace referencia en la nota anterior, en particular, el siguiente párrafo: "El narrador se orienta en una situación proveniente de una tradición oral original y un intercambio de experiencias simétrico entre hablante y oyente. Hay que entender lo que intenta poner en obra como una suerte de restitución, una rememoración de una unidad en la que confluyen sin distinción recuerdo y olvido, las aguas del recuerdo y aquéllas del olvido. Los escenarios de la memoria han de entenderse aquí como manifestaciones de esta indistinción. Y sus edificaciones artificia- 
les son edificaciones de ingenuidad épica. El narrador se presenta aquí como una suerte de profeta que se vuelve hacia atrás, toma el oyente de la mano y evoca la unidad de una experiencia, hace surgir un mundo primitivo que se presenta antes de que nuestro estar en el mundo empieza a dividirse y separarse en dualismos, especialmente antes de aquella división que conocemos como ruptura entre creencia y saber. En la ingenuidad épica toma la palabra una sabiduría que no tiene que legitimarse ante nada y nadie" (Lypp, 2010, 183, trad. de la cita: A. M. R.).

3 La cita reproduce esencialmente la traducción española realizada por $\mathrm{M}$. Löwy, aunque hemos corregido algunas imprecisiones. La traducción de Löwy dice: "El verdadero rostro de la historia se aleja al galope. Sólo retenemos el pasado como una imagen que, en el instante mismo en que se deja reconocer, arroja una luz que jamás volverá a verse. 'La verdad [ya] no se nos escapará': estas palabras de Gottfried Keller caracterizan con exactitud, en la imagen de la historia que se hacen los historicistas, el punto en que el materialismo histórico, a través de esa imagen, se abre paso. Irrecuperable, en efecto, es cualquier imagen del pasado que amenace desaparecer con cada instante presente que, en ella, no se haya dado por aludido" (Löwy, 2003, 71).

4 Reyes Mate recalca en su ensayo sobre las Tesis que el pasado que llega al presente es el de aquéllos que no han sido escuchados, esto es, de los vencidos, los "sin-nombre", cuyas historias aún no han sido narradas. Partiendo de estas ideas, Mate reclama en su libro: "Si la historia es contar hechos, como quiere el histo- ricismo, que los cuente todos y que lo cuente todo." "El pasado tiene vida propia, sorprende a la conciencia presente, toma la iniciativa. [...] Se trata de leer el pasado como un texto que incluso nunca fue escrito. [...] Olvido es desprecio hermenéutico de los sinnombre" (Mate, 2006, 45, 46). Cf. en la misma línea también el artículo de María Teresa de la Garza Camino que resalta que recordar "es hacer presentes las preguntas sin responder, los derechos pisoteados, las injusticias cometidas contra las víctimas" (de la Garza Camino, 2007, 183).

5 Es importante resaltar este punto, puesto que "zuwenden" suele traducirse al castellano como "volverse hacia", lo cual da pie a que se infiltre, con el verbo "volver", precisamente el sentido contrario al que apunta la cita.

6 Mosès, que también pone el énfasis -como lo hemos hecho aquí- en el presente de la mirada del ángel de la historia, diferencia el tipo de presente aterrador al que se enfrenta el ángel -una "presencia de la repetición, maldición, del entumecimiento sin salida"- de otro presente más esperanzador que hace posible la "renovación e invención" (p. 151). En estas dos vertientes del presente se reflejan las otras dos dimensiones temporales: el pasado y el futuro. En este punto es donde Mosès encuentra el aspecto más fundamental del "Jetztzeit" -"tiempo-ahora"- que consiste en que el presente sea "vivido como una re-actualización permanente del pasado, como un intento retomado una y otra vez de llenar lo ignorado de antaño, lo despreciado, sacrificado con nueva vida". Esto significa, según Mosès la "anticipación de la utopia en el presente", una utopía que Benjamin entiende como una "función de la memoria" (p. 153). La constante inversión de pasado, presente y futuro, a la que hemos apuntado mostrando los giros temporales que implica la figura del ángel de la historia, proporciona también la base de la interpretación de Mosès. Como afirma el autor, "Benjamin... ofrece una concepción de la historia en la que nada en la historia queda sacrificado o perdido para siempre. Si todo momento del pasado puede re-actualizarse, desenvolverse de nuevo bajo otras condiciones, en un escenario nuevo, entonces no hay nada en la historia del hombre que no se pueda reparar. $Y$ así, al mismo tiempo, no hay nada inevitable en el futuro" (Mosès, 1994, 158, trad. de las citas: A. M. Rabe).

7 La cita pertenece a un artículo de Herta Wolf en el que la autora analiza la fotografía como archivo de monumentos. El texto forma parte de un volumen editado por la misma auto$r a$ que recoge una serie de estudios sobre el paradigma de la fotografía y la crítica fotográfica a finales de la era fotográfica (Wolf, 2002).

8 En 1958, Meydenbauer, entonces director de la Oficina Estatal de Construcciones, había recibido el encargo de medir en Wetzlar la altura de la fachada de la catedral. Meydenbauer casi se mató en el intento al usar sogas y aparejos. Se le ocurrió entonces recurrir a fotografías y usarlas trigonométricamente deduciendo de alli las medidas exactas del edificio. De esta manera se inventó la fotogrametria que hacia posible medir a distancia sin la necesidad de exponerse a la lluvia, el viento y el peligro.

9 La institución de Meydenbauer realizó hasta el año 19071.050 fotografías de gran tamaño en 225 ciudades, y en 1909/10 obtuvo el encargo de 
los gobiernos de Grecia y Alemania de crear un inventario en imagen y medida de monumentos arquitectónicos griegos de la antigüedad y la Edad Media.

10 Von Bucovich había comenzado en 1928 en la editorial Albertus con una serie de libros titulada "El rostro de las ciudades" ("Das Gesicht der Städte"), de los que finalmente sólo aparecieron los dos libros mencionados.

11 Tras los dos libros de Berlín y París, Bucovich siguió retratando grandes metrópolis. En 1935 apareció el tomo "Photographs" de Londres. A partir de 1936, Bucovich vivió en Nueva York y produjo el tomo "Washington D.C.: City Beautiful". En 1937 apareció en Nueva York el último libro que se conoce de él: "Manhattan Magic. A Collection of Eighty-Five Photographs". En 1937 hizo un viaje en la "Queen Mary" donde escribió el prefacio de su libro sobre Manhattan, tras ese viaje se pierde la pista de Bucovich.

12 Como comenta Flügge, en 1908 Zille tuvo en su casa un archivo de casi 500 fotografias propias que formaban, junto con sus dibujos, la base de su obra. Según Flügge pasarian casi 60 años hasta que se conocieran públicamente (Flügge, 2008, 9).

13 La cita entera es: "'Sólo vemos lo que nos mira. Sólo somos capaces de aquello de lo que no tenemos la responsabilidad'. Nunca se ha entendido la filosofía del flaneûr con más profundidad que con estas palabras que usó Hessel” („'Nur was uns anschaut sehen wir. Wir können nur - ,ofür wir nichts können' Man hat die Philosophie des Flaneurs niemals tiefer erfasst als es Hessel mit diesen Worten getan hat") (Benjamin, 1991c, 198, trad. de la cita: A. M. R.).
14 En su interesante análisis de la figura de la lentitud y desaceleración, que se encuentran en las reflexiones benjaminianas sobre la fotografía en cámara lenta, el flaneûr y el ángel de la historia, Koepnick deja claro que no se puede desvincular el sentido que Benjamin le da a esta figura del contexto de la velocidad de la modernidad, esto es, de la relación dialéctica entre atención y distracción, ni tampoco de sus posibilidades cognitivas. En este sentido resalta Koepnik: "Vivir una vida moderna de creciente aceleración requiere del arte de estar atentos y distraídos al mismo tiempo." El autor resume la "posición de Benjamin sobre la lentitud y el movimiento lento" de la siguiente manera: "Ni su flaneur del siglo XIX, ni su melancólico ángel de la historia pueden ser adecuadamente descritos como practicantes del arte de la desaceleración compensatoria. En vez de huir de los rápidos pulsos de la temporalidad moderna y encontrar descanso en algún imaginario más allá, ellos huyen hacia ellos como para redirigir sus energías. En vez de darle la espalda a la aceleración moderna, se involucran en ella como para abrir espacios alternativos de experiencia" (Koepnik, 2007, 186, 199).

15 Carol Bernstein, que interpreta los espacios vacíos y las calles desiertas de la ciudad en el contexto de la "pérdida de lo humano" (p. 42), esto es, el "desvanecer" del "rostro humano" (p. 44) en el "fenómeno inhumano" de la multitud (p. 43), apunta también a las historias abiertas que, señaladas por el vacío de manera negativa, se encuentran a la espera de ser contadas. En este sentido afirma: "Aqui, entonces, tenemos otra forma de inversión en la que el vacío, lejos de ser el signo de la nada, señala una historia que todavía está por recuperarse" (Bernstein, 1993, 45).

16 Una interpretación de la metáfora y percepción benjaminiana del ángel y la "Columna de la Victoria" en relación con los demás ángeles de Berlín, así como en relación con el camino que Benjamin emprende del "Ángel de la Victoria" al "Ángel de los Vencidos" ofrece el sugerente artículo de José María González Garcia, 2010, 6-17.

17 La cita original es: "0 braungebackne Siegessäule mit Winterzucker aus den Kindertagen" (traducción de la cita por la autora). En este lema Benjamin cita un verso que él mismo había creado unos años atrás bajo la influencia del hachis.

18 Sobre el importante papel que la sensibilidad juega en la poética benjaminiana del recuerdo y la memoria, hecho que se manifiesta con bastante claridad en los escritos de Benjamin sobre su infancia en Berlín, véase el inspirador artículo de Ricardo Pinilla (Pinilla, 2010).

19 En su artículo sobre la "ciudad fantasma" de Benjamin, Karl Heinz Bohrer relaciona la "metáfora del pastelero" en el lema de Infancia con el método benjaminiano de invertir "afuera" y "adentro", un procedimiento que se mantiene, según Bohrer, también en la obra de los Pasajes. En el caso de la Columna Triunfal es interesante destacar la transformación del monumento producida mediante esta inversión, que Bohrer describe de la siguiente manera: "Como lema sirve la metáfora del pastelero que ya había aparecido en el texto de Moscú: la amenaza arquitectónica del monumento conmemorativo de una victoria histórica de Prusia que provocó un cambio político en Europa queda transformada en una fantasía par- 
ticular de la imagen de la infancia. El afuera más extremo se convierte en un adentro más profundo. $Y$ de esta manera, es significativo, para el poder del interior, que el interior predomine incluso alli donde habria ocasión de representar un Berlín exterior" (Bohrer, 1999, 485, trad. de esta cita: A. M. R.).

20 La traducción española de Klaus Wagner es aqui deficiente.

21 Esto mismo lo observa Ranke afirmando que los comentarios de Benjamin acerca de las fotografias de Atget se pueden aplicar también a las fotografías de Zille (Ranke, 1975, 36-37).

\section{BIBLIOGRAFÍA}

Adam, Hans Christian (ed.) (2000): Paris. Eugène Atget 1857-1927, Colonia, Taschen.

Bucovich, Mario von (1928): Berlin, con un prefacio de Alfred Döblin, Berlín, Albertus; reedición en: von Bucovich (1992): Berlin 1928. Das Gesicht der Stadt, Berlín, Nicolai.

Benjamin, Walter (1973a): La obra de arte en la época de su reproductibilidad técnica, en Benjamin, Walter: Discursos Interrumpidos I, prólogo, traducción y notas de J. Aguirre, Madrid, Taurus, 15-57.

Benjamin, Walter (1973b): Pequeña historia de la fotografía, en Benjamin, Walter: Discursos Interrumpidos I, prólogo, traducción y notas de J. Aguirre, Madrid, Taurus, 61-83.

Benjamin, Walter (1990): Infancia en Berlín hacia 1900, traducción de K. Wagner, Madrid, Alfaguara (3. ${ }^{\text {e ed.). }}$.

Benjamin, Walter (1991a): El narrador, en Benjamin, Walter: Iluminaciones IV, traducción de R. Blatt, introducción y selección de E. Subirats, Madrid, Taurus, 111-134.
Benjamin, Walter (1991b): Über den Begriff der Geschichte, en Benjamin, Walter, Gesammelte Schriften, vol. I, n. ${ }^{\circ}$ 2., ed. por R. Tiedemann/H. Schweppenhäuser, Francfort del Meno, Suhrkamp, 691-704.

Benjamin, Walter (1991c): Die Wiederkehr des Flaneurs, en Benjamin, Walter, Gesammelte Schriften, vol. III, ed. por R. Tiedemann/H. Schweppenhäuser, Francfort del Meno, Suhrkamp, 194199.

Benjamin, Walter (1991d): Das Paris des Second Empire bei Baudelaire, en Benjamin, Walter, Gesammelte Schriften, vol. I, n. ${ }^{\circ}$, ed. por R. Tiedemann/H. Schweppenhäuser, Francfort del Meno, Suhrkamp, 511-604.

Benjamin, Walter (1991e): Berliner Kindheit um Neunzehnhundert, en Benjamin, Walter, Gesammelte Schriften, vol. IV, n. ${ }^{0}$ 1, ed. por R. Tiedemann/ H. Schweppenhäuser, Francfort del Meno, Suhrkamp, 235-304.

Bernstein, Carol L., (1993): Encrucijadas: La poética urbana de Walter Benjamin, en Klerk, Claudia (ed.), En torno a Walter Benjamin, México, Colección Cultura Universitaria, 23-50.

Bohrer, Karl Heinz (1999): Benjamins Phantasma-Stadt: Labyrinth zwischen "Ereignis" und "Interieur", en Garber, Klaus/Rehm, Ludger (ed.), Global benjamin. Internationaler Benjamin-Kongreß 1992, Múnich/Paderborn, Wilhelm Fink, 478-493.

Eugène Atget. Retrospektive, catálogo (2007), Martin-Gropius-Bau Berlín, Berlín, Nicolai.

Flügge, Matthias (2008): Ein Berliner Leben. Heinrich Zilles Werk vor dem Ersten Weltkrieg, en Flügge, Matthias, H. Zille. Berliner Leben. Zeichnungen, Photographien und Druckgraphiken 1890-1940, Berlin/Munich, Akademie der Künste/Schirmer/Mosel, 535.
Garza Camino, María Teresa de la (2007): Tiempo y memoria en Walter Benjamin, en Finkelde, D.; Webels, E.; de la Garza Camino, T. y Mancera, F. (ed.), Topografías de la modernidad. El pensamiento de Walter Benjamin, México, UNAM/Universidad Iberoamericana/Goethe-Institut México, 173-183.

González García, José María (2010): Paseos benjaminianos por los ángeles de Berlín, en Afinidades, n. ${ }^{\circ} 3$.

Klünner, Hans-Werner (ed.) (2001): Berliner Plätze. Photographien von Max Missmann. Berlin, Nicolai.

Koepnik, Lutz (2007): Slow motion: Benjamin y las políticas de desaceleración, en Finkelde, D.; Webels, E.; de la Garza Camino, T. y Mancera, F. (ed.), Topografías de la modernidad. El pensamiento de Walter Benjamin, México, UNAM/Universidad Iberoamericana/Goethe-Institut México, 185-200.

Löwy, Michael (2003): Walter Benjamin. Aviso de incendio. Una lectura de las tesis "Sobre el concepto de historia", Buenos Aires, Fondo de Cultura Económica de Argentina.

Mate, Reyes (2006): Medianoche en la historia: comentarios a las tesis de Walter Benjamin "Sobre el concepto de historia", Madrid, Trotta.

Mosès, Stéphane (1994): Der Engel der Geschichte. Franz Rosenzweig, Walter Benjamin, Gershom Scholem, Francfort del Meno, Jüdischer Verlag.

Lypp, Bernhard (2010): Schauplätze des Gedächtnisses. Reflexionen auf den Spuren von Walter Benjamin", en Akzente. Zeitschrift für Literatur, ed. Michael Krüger, n. 2, abril, 181191.

Pinilla, Ricardo (2010, en prensa): Memoria y sensibilidad en la obra de Walter Benjamin, en Bajo Palabra, n. ${ }^{\circ}$ 5, 6978. 
Ranke, Winfried (1975): Heinrich Zille Photographien Berlin 1890-1910, Munich, Wilhelm Heyne.

Riegl, Alois (2007): El culto moderno a los monumentos: su carácter y sus orígenes, primera edición antológica y comentada en español por Aurora Arjones Fernández, Sevilla, Junta de Andalucia, Consejería de Cultura.
Scheler, Max/Harder, Matthias (ed.) (2000): Herbert List, Munich, Schirmer/Dosel.

Tupitsyn, Margarita (1998): Alexander Rodtschenko. Das neue Moskau, Munich, Schirmer/Dosel.

Umbo Photographien 1925-1933, catálogo (1979), Hannover/Gödicke, Kunstmuseum Hannover.
Wietzorek, Paul, 2008: Das historische Berlin. Bilder erzählen, Petersberg, Michael Imhof.

Wolf, Herta (2002): Das Denkmälerarchiv Fotografie, en Wolf, Herta (ed.), Paradigma Fotografie. Fotokritik am Ende des fotografischen Zeitalters, vol. 1, Francfort del Meno, 349375.

\section{Relación de imágenes}

1. Siegesallee, Berlín, hacia 1910 (Wietzorek, 2008, 184185).

2. Monumento a Bismarck y Columna da la Victoria, Berlín, 1915 (Wietzorek, 2008, 181).

3. El edificio del Reichstag (Parlamento), Berlín, hacia 1930 (Colección Eickemeyer, Berlín).

4. El edificio destruido del Reichstag, Berlín, 1945 (Colección Eickemeyer, Berlín).

5. M. Missmann, vista hacia la Puerta de Brandenburgo desde la Friedensallee, Berlín 1910 (Klünner, 2001, 65).

6. La Puerta de Brandenburgo, Berlín, tras la $2^{\text {a Guerra }}$ Mundial (Colección Eickemeyer, Berlín).

7. Postal del edificio del Parlamento (Reichstag) al terminarse de construir en 1894 (bpk Berlin, publicon Verlagsgesellschaft $\mathrm{mbH}$, Berlín).

8. Mario v. Bucovich, vista al Reichstag desde el río Spree, 1928 (v. Bucovich, 1992).

9. M. Missmann, vista de la Plaza Belle-Alliance, 1904 (Klünner, 2001, 61).

10. M. v. Bucovich, vista de la Plaza Belle-Alliance, 1928 (v. Bucovich, 1992).

11. M. Missmann, Plaza de Kemper y Avenida de la Victoria (Siegesallee), 1925 (Klünner, 2001, 77).

12. M. v. Bucovich, vista de la Siegesallee, 1928 (v. Bucovich, 1992).

13. Postal del Palacio de los Hohenzoller y del Puente del Palacio, hacia 1930, Berlín (Colección Eickemeyer, Berlín).

14. M. v. Bucovich, Palacio de los Hohenzoller y Puente del Palacio, 1928 (v. Bucovich, 1992).

15. Postal del monumento a Federico Guillermo IV y de la Catedral, Berlín (Wietzorek, 128).
16. M. v. Bucovich, Estación de Friedrichstraße, al fondo: vista de la Catedral, 1928 (v. Bucovich, 1992).

17. M. v. Bucovich, masas saliendo del metro, Berlín, 1928 (v. Bucovich, 1992).

18. M. v. Bucovich, en la plaza de la estación del Zoológico, Berlín, 1928 (v. Bucovich, 1992).

19. M. v. Bucovich, gente buscando cobijo de la lluvia, Berlín, 1928 (v. Bucovich, 1992).

20. M. v. Bucovich, sombras en la calle, Berlín, 1928 (v. Bucovich, 1992).

21. H. Zille, recolectoras de chasca, vista al puente de Knobelsdorff, Berlín, otoño de 1898 (Flügge, 2008, 54).

22. H. Zille, tres hombres volviendo a casa, Sopie-Charlotten -Straße, al fondo: Knobelsdorffstraße. Berlín, otoño de 1898 (Flügge, 2008, 83).

23. H. Zille, Parochialstraße 23 y 24 , entre Jüden- y Klosterstraße, Berlín, 1902/1903 (Flügge, 2008, 143).

24. H. Zille, ribera del Spree, al fondo: torre del Stadthaus, Berlín, 1910 (Ranke, 1975, 119).

25. H. Zille, en la puerta del Palacio de Charlottenburg, Berlin (Ranke, 1975, 114).

26. H. Zille, sombra en una casa, Berlín, hacia 1890 (Ranke, 1975, 62).

27. H. Zille, esquina de una casa y muro en el "Krögel", Berlín, 1902 (Flügge, 2008, 141).

28. H. Zille, "Krögel", vista desde el segundo patio al primero, Berlín, 1896/1897 (Flügge, 2008, 179).

29. E. Atget, Boulevard Saint-Denis, París, 1926 (Adam, 2000, 70).

30. E. Atget, Entrada de la cour du Dragon en la rue du Dragon, Paris, 1913 (Adam, 2000, 98).

31. E. Atget, Calle Saint-Médard, Paris, 1899 (Eugène Atget, 2007, 12).

ARBOR Vol. 187747 enero-febrero [2011] 143-168 ISSN: 0210-1963 
32. E. Atget, Passage du grand Cerf, París, 1907 (Eugène Atget, 2007, 165).

33. E. Atget, Collège de Chanac, París, 1900 (Eugène Atget, 2007, 190).

34. E. Atget, Versailles, París, 1903 (Adam, 2000, 231).

35. Café "A I'Homme Armé", Paris, 1900 (Adam, 2000, 169).

36. Marché des Carmes, París 1910-11 (Eugène Atget, 205).
37. Umbo, Noche en la pequeña ciudad (Salzburgo), 1930 (Umbo Photographien, 1979).

38. A. Ródchenko, Desfile de deportistas en la Plaza Roja, Moscú, 1930 (Tupitsyn, 1998).

39. H. List, Alemania marcha, París 1937 (Scheler/Harder, 2000).

40. H. List, Clochard bajo un monumento, París, 1936 (Scheler/Harder, 2000). 